

\section{DISCLAIMER}

This report was prepared as an account of work sponsored by an agency of the United States Government. Neither the United States Government nor any agency Thereof, nor any of their employees, makes any warranty, express or implied, or assumes any legal liability or responsibility for the accuracy, completeness, or usefulness of any information, apparatus, product, or process disclosed, or represents that its use would not infringe privately owned rights. Reference herein to any specific commercial product, process, or service by trade name, trademark, manufacturer, or otherwise does not necessarily constitute or imply its endorsement, recommendation, or favoring by the United States Government or any agency thereof. The views and opinions of authors expressed herein do not necessarily state or reflect those of the United States Government or any agency thereof. 


\section{DISCLAIMER}

Portions of this document may be illegible in electronic image products. Images are produced from the best available original document. 


\title{
1980 ANNUAL REPORT INEL GEOTHERMAL ENVIRONMENTAL PROGRAM
}

\author{
Lorie S. Cahn
}

Thomas L. Thurow

Julie A. Martinez

EARTH AND LIFE SCIENCES

Published April 1981

EG\&G Idaho, Inc. Idaho Falls, Idaho 83415

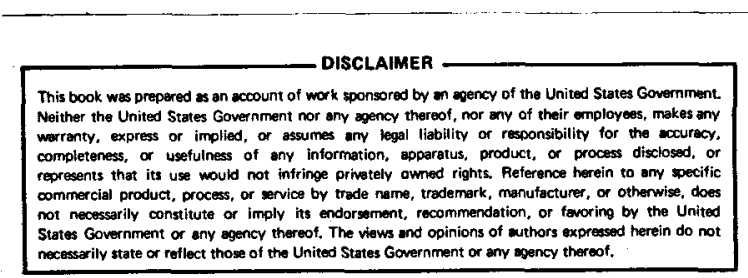

Prepared for the

U.S. Department of Energy Idaho Operations Office

Under DOE Contract No. DE-AC07-76ID01570 


\section{ABSTRACT}

This report summarizes the environmental monitoring efforts at the Raft River Geothermal Site during 1980. The Raft River Environmental Program is designed to assess the beneficial and detrimental impacts to the environment resulting from developing a moderate-temperature geothermal resource. This research contributes to an understanding of the local physical, biological and human environment and provides baselire data to be used in formulating management decisions that will reduce potential long-term detrimental impacts to the environment. 
During the past seven years of the Geothermal Environmental Program, several individuals and agencies have provided much appreciated technical advice and support. We owe special thanks to E. G. Crosthwaite, formerly of the U.S. Geological Survey; R. Howard, U.S. Fish and Wildlife Service;

J. Pribble, N. Cozakos, and K. Carter, Bureau of Land Management; the staff of the Idaho Department of Water Resources; R. 01sen, Idaho Department of Fish and Game; and J. Cate, National Oceanic and Atmospheric

Administration. C. Lewis of Lewis and Associates performed the Raft River/Cassia County Socioeconomic Survey. J. Allan of the University of Utah Research Institute (UURI) performed the vegetation study. J. Barnes, and D. Shiozawa of Brigham Young University (BYU) conducted the aquatic survey of the Raft River. C. White and D. Johnson of BYU participated in the raptor population research and assisted J. Gesseman of Utah State University on the raptor radiotelemetry study. A. Nelson, C. Tuckfield, W. Divine, and C. White of BYU performed the songbird survey. D. Crow of Erco, Inc. designed the air quality monitoring network and has been responsible for the data analys is with $K$. Reheis. The seismicity study was conducted by S. Schaff of UURI. The pygmy rabbits were studied by J. Flinders, L. Conde, and C. Flinders of BYU. To all of these individuals and organizations we extend our sincere thanks and gratitude. 


\section{CONTENTS}

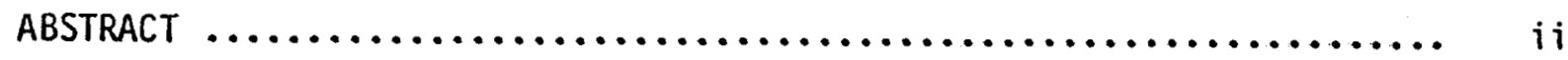

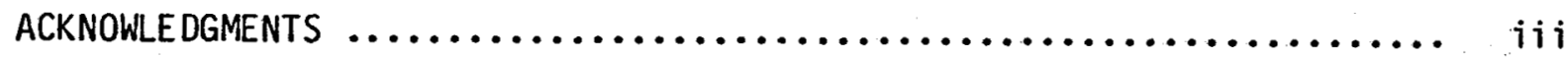

INTRODUCTION $\ldots \ldots \ldots \ldots \ldots \ldots \ldots \ldots \ldots \ldots \ldots \ldots \ldots \ldots \ldots \ldots \ldots \ldots \ldots \ldots \ldots$

RAFT RIVER GEOTHERMAL DEVELOPMENT $\ldots \ldots \ldots \ldots \ldots \ldots \ldots \ldots \ldots \ldots \ldots \ldots$

PHYSICAL ENVIRONMENT MONITORING PROGRAMS $\ldots \ldots \ldots \ldots \ldots \ldots \ldots \ldots \ldots \ldots . \ldots$

Monitor wells $\ldots \ldots \ldots \ldots \ldots \ldots \ldots \ldots \ldots \ldots \ldots \ldots \ldots \ldots \ldots \ldots \ldots \ldots$

Introduction $\ldots \ldots \ldots \ldots \ldots \ldots \ldots \ldots \ldots \ldots \ldots \ldots \ldots \ldots \ldots$

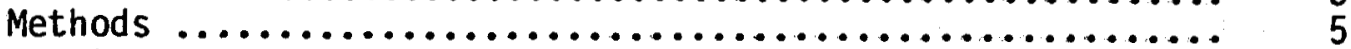

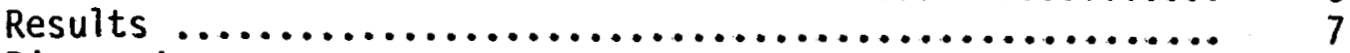

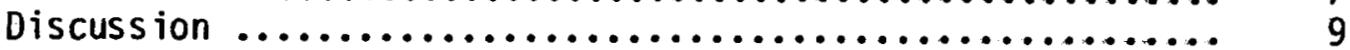

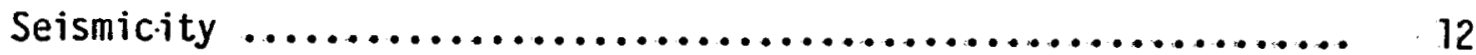

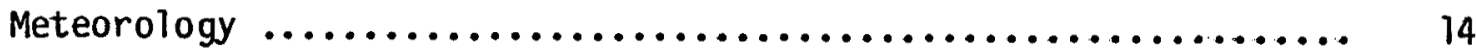

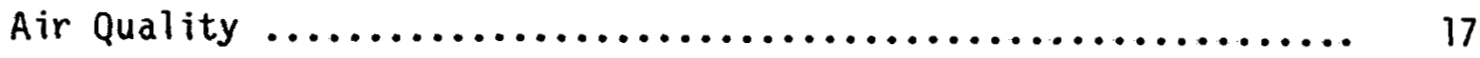

Introduction $\ldots \ldots \ldots \ldots \ldots \ldots \ldots \ldots \ldots \ldots \ldots \ldots \ldots \ldots \ldots \ldots \ldots$

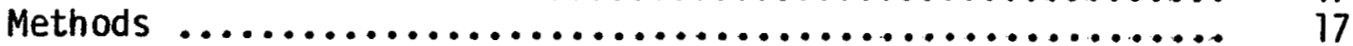

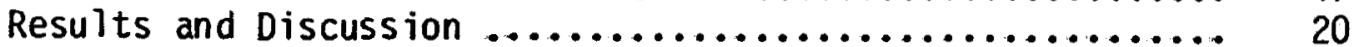

BIOLOGICAL ENVIRONMENT MONITORING PROGRAMS $\ldots \ldots \ldots \ldots \ldots \ldots \ldots \ldots \ldots \ldots$

Plant Ecology................................... 23

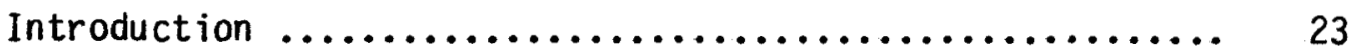

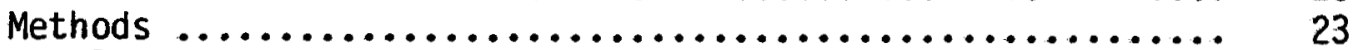

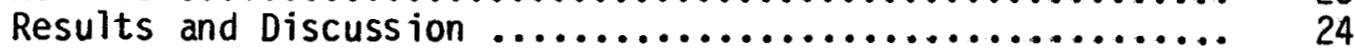

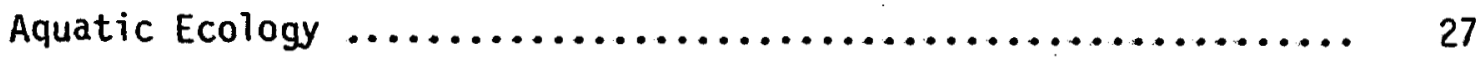

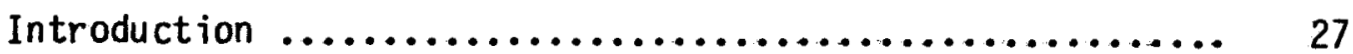

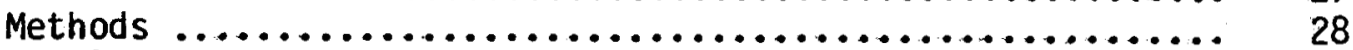

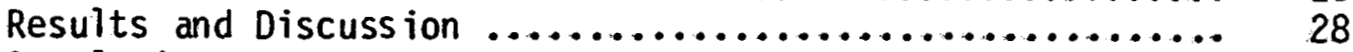

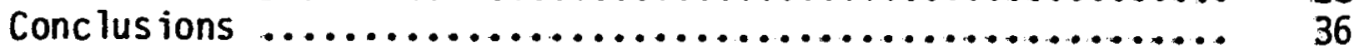

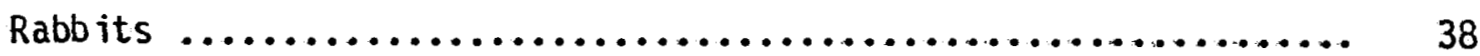

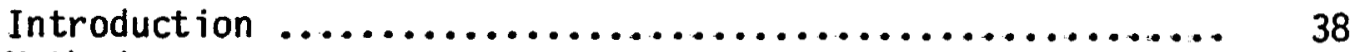

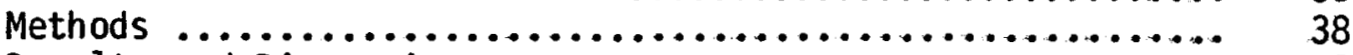

Results and Discussion .......................... 41 
Raptors $\ldots \ldots \ldots \ldots \ldots \ldots \ldots \ldots \ldots \ldots \ldots \ldots \ldots \ldots \ldots \ldots \ldots \ldots, \quad 43$

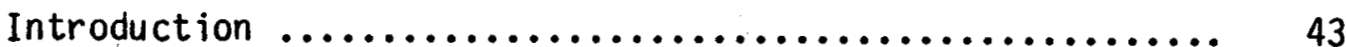

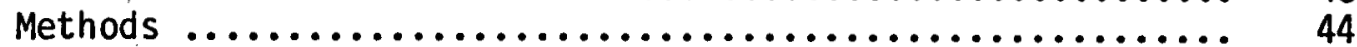

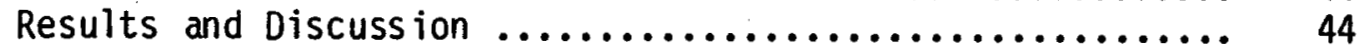

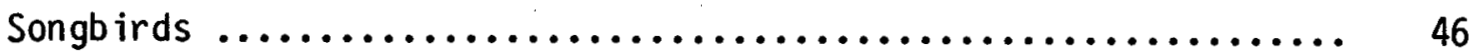

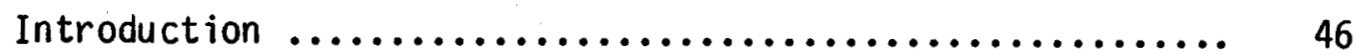

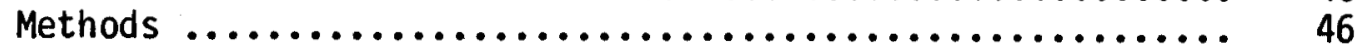

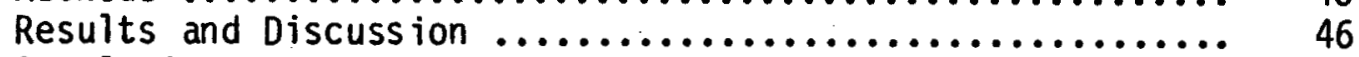

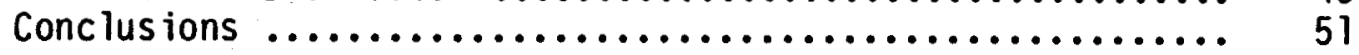

HUMAN AND CULTURAL MONITORING PROGRAMS $\ldots \ldots \ldots \ldots \ldots \ldots \ldots \ldots \ldots \ldots \ldots$

Socioeconomics $\ldots \ldots \ldots \ldots \ldots \ldots \ldots \ldots \ldots \ldots \ldots \ldots \ldots \ldots \ldots \ldots \ldots \ldots$

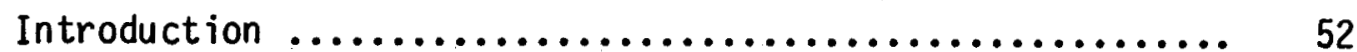

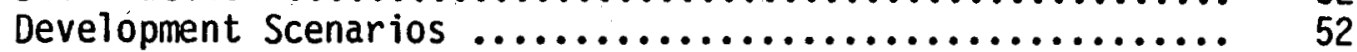

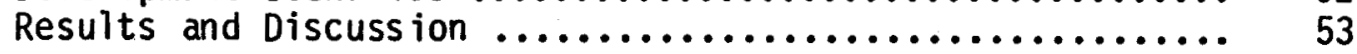

Fluoros is $\ldots \ldots \ldots \ldots \ldots \ldots \ldots \ldots \ldots \ldots \ldots \ldots \ldots \ldots \ldots \ldots \ldots \ldots \ldots$

Introduction ............................... 57

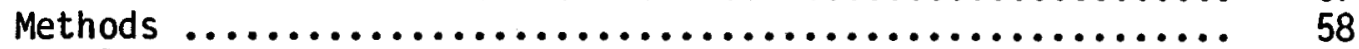

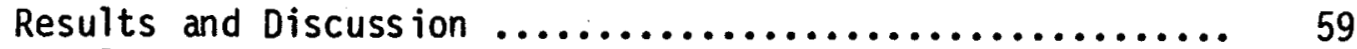

Conclusions .................................. 62

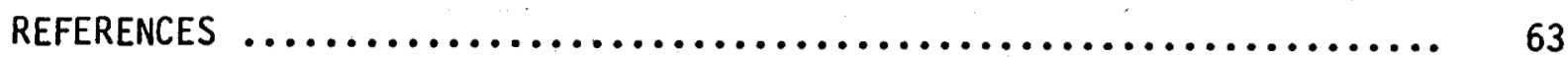

FIGURES

1. Location of Raft River geothermal, monitor, and irrigation wells $\ldots \ldots \ldots \ldots \ldots \ldots \ldots \ldots \ldots \ldots \ldots \ldots \ldots \ldots \ldots \ldots \ldots . . \ldots \ldots$

2. Hydrographs of monitor wells $\ldots \ldots \ldots \ldots \ldots \ldots \ldots \ldots \ldots \ldots \ldots \ldots$

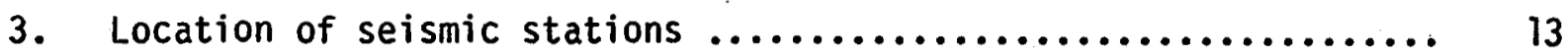

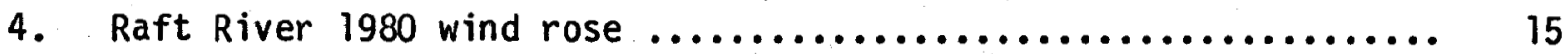

5. Raft River (Malta) 1980 average monthly precipitation ......... 16

6. Raft River (Malta) 1980 average monthly temperatures ......... 16

7. Location of air quality monitoring stations .............. 19

8. Location of permanent vegetation plots $\ldots \ldots \ldots \ldots \ldots \ldots \ldots \ldots \ldots . \ldots 25$ 
9. Map of aquatic stations on the Raft River ................ 29

10. Location of rabbit transects and songbird grids ............ 40

\section{TABLES}

1. Chemical analysis of monitor wells $\ldots \ldots \ldots \ldots \ldots \ldots \ldots \ldots \ldots \ldots$

2. 24-hour average concentration of environmental pollutants near RRGE-2, Raft River ............................ 18

3. Average total suspended particulates (TSP) concentrations ...... 22

4. Concentrations of total dissolved solids (TOS) at Raft River sampling stations ................................ 31

5. Catchability of fish species in Raft River $\ldots \ldots \ldots \ldots \ldots \ldots \ldots \ldots$

6. Estimated densities of the fish population using seining

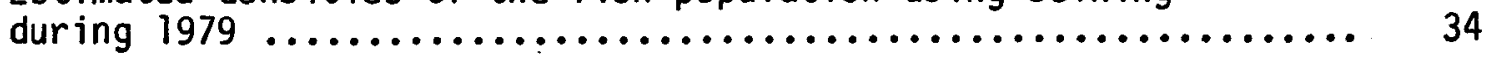

7. - Density of Raft River invertebrates by functional group ....... 37

8. Percent relative frequencies of plant overstory and percent cover of understory at the songbird sites ................. 48

9. Songbird species encountered on study sites and their

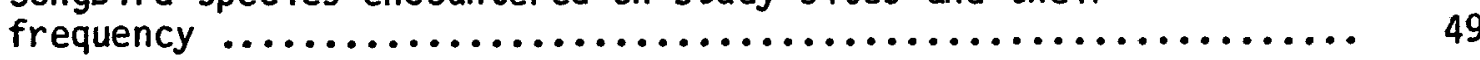

10. Density of major breeding songbirds on 16-ha plots .......... 50

11. Summary of employment, labor source, and population impacts .... 56 
INTRODUCTION

The 1980 annual report provides an overview of continuing environmental research and monitoring programs conducted at the Raft River Geothermal site during the past seven years. The monitoring programs are designed to collect data on the physical, biological and human environments of the development area. These data are used to predict and evaluate potential environmental impacts from geothermal development, and to prevent significant changes.

Primary research during 1980 emphasized completing baseline studies on terrestrial fauna, establishing an air quality monitoring network, investigating potential sources of fluoride in the Raft River Valley, and studying water level changes in the shallow monitor wells in response to development of the geothermal resource.

\section{RAFT RIVER GEOTHERMAL DEVELOPMENT}

The Department of Energy (DOE), in a cooperative agreement with the State of Idaho and the Raft River Rural Electric Cooperative, has provided support to the Raft River Geothermal Program since its inception in 1973. The objective of the program is to demonstrate the use of moderate temperature $\left(150^{\circ} \mathrm{C}\right)$ geothermal water to generate electricity and to provide energy for direct-use applications. Development at the Raft River known Geothermal Resource Area (KGRA) includes seven deep wells (drilled between 1975 and 1977), and a 5-MW(e) power plant. Construction on the plant was completed in late 1980, however, grooming and testing of the operation systems are continuing.

Direct applications research in 1980 using geothermal fluids included biomass conversion for liquid fuel, lignin/cellulose conversion for alcohol production, aquaculture research, and geothermal wetlands investigations. The reservoir assessment program included long-term reservoir tests to evaluate production and injection capabilities of the geothermal aquifer. 
The continuing environmental research and monitoring studies aid in understanding the interrelationships of the biotic and abiotic components of the environment. This understanding is essential in recognizing and preventing significant changes which may occur during geothermal development. This is especially critical because the delicate cold-desert ecosystem of the Raft River Valley is very susceptible to degradation. once destroyed, this ecosystem is difficult to reestablish and requires a long time to regenerate. 
The physical components of the environment have an effect on the entire ecosystem of an area. Air quality, water quality, and seismicity are monitored at the Raft River site to detect potential changes occurring as a result of geothermal development. These programs are essential to ensure effective management and protection of the area resources.

\section{Monitor Wells}

Introduction

The Raft River Valley is a structurally downthrown bas in filled with $1800 \mathrm{~m}$ of sediments derived from the surrounding mountain ranges. Two formations are distinguished in the valley fill. The lower Tertiary Salt Lake Formation over lies Precambrian quartzite, schist, and quartz monzonite, and consists of approximately $1600 \mathrm{~m}$ of poorly consolidated quartzose silts and sands, tuff, and gravel. The upper Raft Formation is composed of approximately $200 \mathrm{~m}$ of sand, gravel, silt and clay.

The five deep production wells drilled at the Raft River Geothermal Site terminate in the Precambrian basement. The two injection wells terminate in the intermediate zone of the Salt Lake Formation, and the seven monitor wells terminate in the shallow zone of the Salt Lake Formation. Figure 1 shows the placement and depths of all the wells at the Raft River development area.

Ground water in the basin occurs in confined and unconfined conditions in both the Raft Formation and the Salt Lake Formation. Precipitation in the surrounding mountains and infiltration from streams and irrigation water recharges these aquifers. Ground water withdrawal for irrigation has increased substantially since 1948. Irrigation wells clustered within $3 \mathrm{~km}$ of the Raft River have caused severe water table declines. Surface and groundwater withdrawals for irrigation have resulted in totally dissipated 


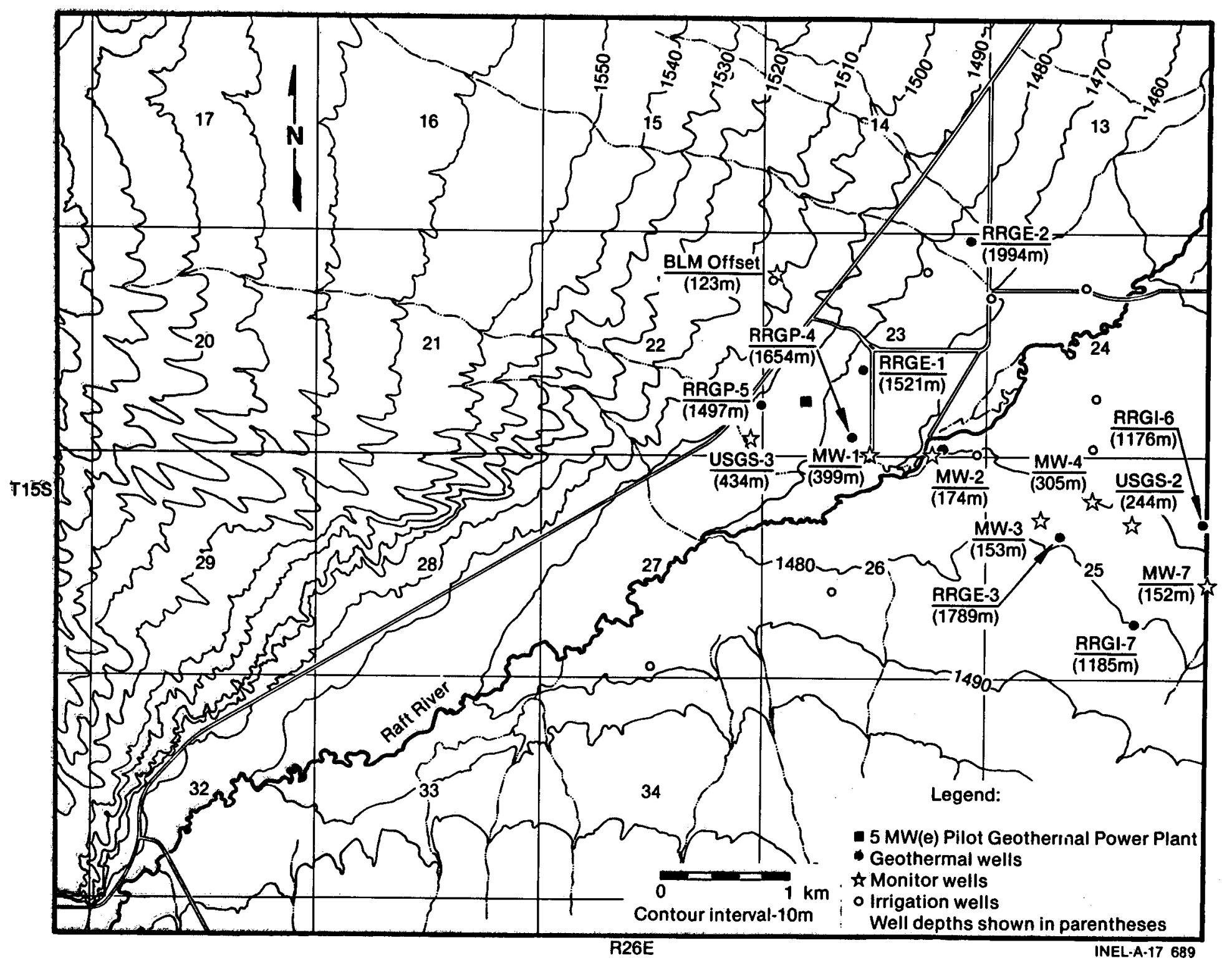

Figure 1. Location of Raft River geothermal, monitor, and irrigation wells. 
flow in the river north of the geothermal site between Bridge and Malta. Records of ground water levels in irrigation wells since 1952 show more than $15 \mathrm{~m}$ of decline north of Malta and nearly $6 \mathrm{~m}$ of decline just east of the geothermal development area. In 1963, the State of Idaho declared the basin a critical ground water area, closing it to further ground water deve lopment.

Shallow wells in the basin generally penetrate water table aquifers, however, some reveal locally confined conditions. Several of the deep geothermal production wells have piezometric surfaces that are over $100 \mathrm{~m}$ above the land surface. Because of this increase in head with depth, each aquifer is probably recharged, in part, by upward leakage from underlying aquifers. In the geothermal area, wells as shallow as $120 \mathrm{~m}$ tap hot water. Most of the irrigation wells in the area show chemical and thermal evidence of upward leakage from the geothermal resource.

An irrigation well monitoring program was established in 1974: 1) to determine the extent of natural communication between aquifers in the Raft River Basin, 2) to monitor the chemical and hydrologic effects of the geothermal development, and 3) to predict the long-term impact of geothermal development on the shallow aquifers. The initial monitoring programs were conducted by the DOE and the Idaho Department of Water Resources. The data collected had limited usefulness due to uncontrollable problems encountered in using irrigation wells for monitoring. Therefore, in 1976 the decision was made to drill a series of shallow monitor wells at the geothermal development site. The wells were located to detect potential changes before the effects of change could be detected in nearby irrigation and domestic wells.

\section{Methods}

The seven monitor wells have been equipped since 1978 with either a Stevens water level recorder or a digiquartz pressure transducer to provide continuous records of water level fluctuations within each well. Monitor 
well hydrographs reflect both long-term fluctuations and short-term fluctuations which are related to seasonal, barometric, irrigation, and geothermal development influences. An interpretation of the monitor well hydrographs for 1979 revealed the following:

1. The hydrographs depict primarily irrigation withdrawal and recovery characteristics rather than a natural hydrologic cycle.

2. MW-1, USGS-3 and the BLM-offset well are hydraulically connected to the injection zone in RRGI-4. This connection is probably fracture-related. (RRGI-4 has subsequently been deepened, the injection zone cased off, and the name changed to RRGP-4.)

3. Monitor wells $3,4,5,6$, and 7 reflect semiconfined aquifer conditions with barometric efficiencies of $40-60 \%$.

4. MW-4 shows a rapid response to injection at RRGI-6.

5. Monitor wells 5, 6 and 7 show aquifer-distortion responses to injection at RRGI-6.

6. Injection testing at RRGI-7 in 1979 had not been of long enough duration to accurately detect response in the monitor wells.

Two long-term production-injection tests were conducted in 1980 . During the period from May 14 to June 12, RRGE-3 was produced with injection into RRGI-6. On June 12 injection was switched to RRGI-7 for five days. The average pumping rate was 47 lps. The second production test began August 19 and continued to September 10. During this time, RRGE- 1 was produced with injection alternately into RRGI-6 and RRGI-7. The alternating of injection wells was short-term and did not show significant effects on the monitor wells. The average pumping rate for this test was 57 Ips. 
Results

The 1980 monitor well hydrographs (Figure 2) are discussed in detail in a separate monitor well report. ${ }^{2}$ A brief discussion of each hydrograph follows.

Monitor Well 1: The static water level in MW-1 ranged from 30 to $32 \mathrm{~m}$ above the well head. The water level decline and recovery from mid-May to July and August coincided with the RRGE-3 to RRGI-7 test, indicating a possible response to pumping at RRGE-3.

Monitor Well 2: The static water level in MW-2 ranged from 11 to $13.5 \mathrm{~m}$ above the wellhead, showing a general rising trend of $2.5 \mathrm{~m}$. This hydrograph shows the effects of pumping at the nearby, shallow Crook well. A water level rise in mid-June was caused by termination of pumping at the crook well. The subsequent decline in mid-July may have been caused by response to the RRGE -3 to RRGI-6 test.

Monitor Well 3: The static water level at MW-3 ranged from 14 to $16 \mathrm{~m}$ below the wellhead. The major responses of this well correlated with irrigation pumping, showing a general decline from May to September and recovery from 0ctober to the end of the year. The hydrograph for MW-3 shows the possible occurrence of aquifer dilation during the RRGE-3 to RRGI-6 test.

Monitor Well 4: The static water level at MW-4 ranged from 0.5 to $2.5 \mathrm{~m}$ below the wellhead. A water level rise during mid-May and subsequent recovery were in response to the RRGE- 3 to RRGI -6 test. This response correlates to responses observed during injection tests in 1979 that were previously defined as fracture communication.

During the production testing in August-September, the response at MW-4 was less pronounced. Injection was switched from RRGI-6 to RRGI-7 after eight days. The hydrograph shows recovery from injection at RRGI-6 


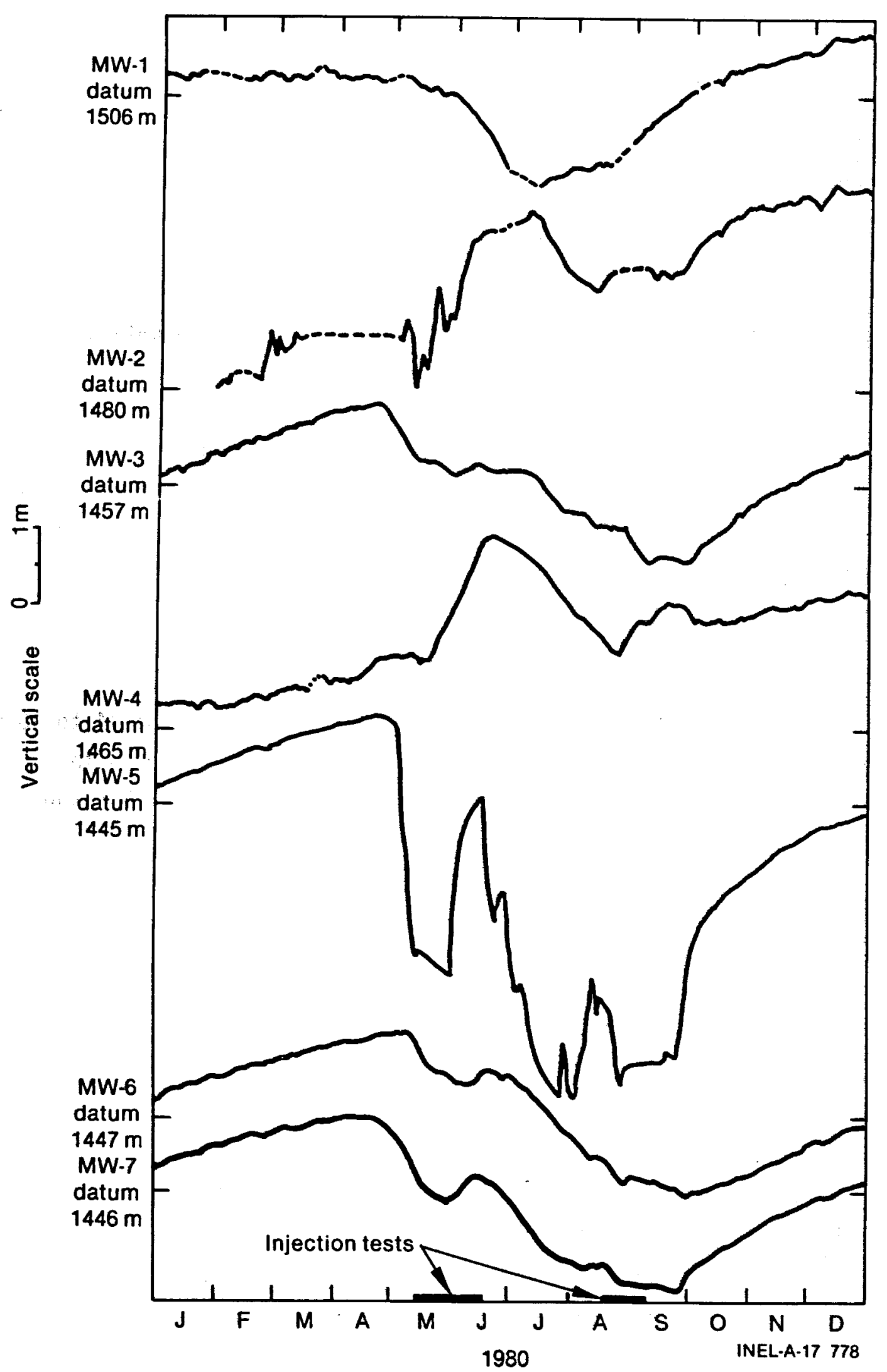

Figure 2. Hydrographs of monitor wells. 
and, to a lesser extent, build-up from injection into RRGI-7. The response to injection at RRGI-7 was of lower magnitude due to greater distance and possibly less hydraulic communication.

Monitor Well 5: The static water level at MW-5 ranged from 20 to $24 \mathrm{~m}$ below the wellhead. The hydrograph shows the seasonal water level decline and recovery due to irrigation pumping. Sharp responses were due to interference from a nearby irrigation well. One such response coincided with the RRGE-3 to RRGI-6 test in June, but it is felt that the response is not caused by the testing.

Monitor Well 6: The static water level at $M W-6$ ranged from 22 to $23 \mathrm{~m}$ below the wellhead. The major response reflected on the hydrograph is due to irrigation pumping with subsequent recovery. Aquifer dilation may have occurred during the RRGE-3 to RRGI-6 test.

Monitor Well 7: The static water level at MW-7 ranged from 24 to $26 \mathrm{~m}$ below the wellhead. The hydrograph for $M W-7$ is very similar to the annual response seen in MW-6 and MW-3.

\section{Discussion}

Water level responses in MW-1 and MW-2 indicate direct hydraulic connection with the geothermal system. A water level decrease could accompany geothermal production, affecting $M W-1, M W-2$, and the BLM and Crook wells. Based on data collected, a response to geothermal injection is not expected in this area.

$M W-3, M W-5, M W-6$, and $M W-7$ respond to seasonal fluctuation and irrigation pumping. The magnitude of response varies, apparently related to distance from irrigation wells. Response to geothermal production or injection is not anticipated in these wells.

MW-4 shows a rapid water level rise in response to geothermal injection. This has been attributed to hydraulic communication caused by inhomogeneities, possibly soft-sediment fractures. 
Water Chemistry: A chemical analysis of water from the monitor wells is given in Table 1. The water chemistry and the bottom hole temperatures confirm that interconnection between shallow and deep aquifers varies spatially. 
TABLE 1. CHEMICAL ANALYSES OF MONITOR WELLS

\begin{tabular}{|c|c|c|c|c|c|c|c|c|c|c|}
\hline & $\begin{array}{l}M W-1 \\
12 / 80\end{array}$ & $\begin{array}{l}\text { MW-2 } \\
12 / 80 \\
\end{array}$ & $\begin{array}{l}M H-3 \\
1 / 80 \\
\end{array}$ & $\begin{array}{l}M W-3 \\
12 / 80 \\
\end{array}$ & $\begin{array}{l}M W-4 \\
12 / 80 \\
\end{array}$ & $\begin{array}{l}M W-5 \\
12 / 80 \\
\end{array}$ & $\begin{array}{l}M W-6 \\
12 / 80 \\
\end{array}$ & $\begin{array}{l}M W-7 \\
12 / 80\end{array}$ & $\begin{array}{l}\text { BLM } \\
12 / 80 \\
\end{array}$ & $\begin{array}{l}\text { Crook } \\
12 / 80 \\
\end{array}$ \\
\hline $\mathrm{SpC}$ & 10,900 & 6,000 & 5,300 & 7,600 & 7,600 & 2,200 & 8,600 & 2,500 & 3,500 & 6,200 \\
\hline Temp. & 74 & 56 & --- & 46 & -- & 25 & 27 & -- & 94 & 95 \\
\hline Hardness & 530 & 300 & $\therefore-$ & 440 & 380 & 320 & 520 & 250 & 130 & 300 \\
\hline Alkalinity. & 30 & 35 & -- & 40 & 26 & 100 & 49 & 92 & 40 & 34 \\
\hline $\mathrm{Ca}^{2+}$ & 205 & 130 & 163 & 170 & 150 & 125 & 210 & 96 & 53 & 120 \\
\hline $\mathrm{Mg}^{2+}$ & .35 & .36 & 3.6 & 2.5 & 2.7 & 1.8 & 1.6 & 3.5 & 24 & 42 \\
\hline $\mathrm{Na}^{+}$ & & & 1,420 & & 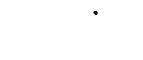 & & & & & \\
\hline$x^{+}$ & 34 & 31 & 22 & 33 & 34 & 25 & 51 & 27 & 21 & 33 \\
\hline $\mathrm{HCO}_{3}-$ & 37 & 43 & 34 & 49 & 32 & 120 & 60 & 110 & 49 & 42 \\
\hline $\mathrm{SO}_{4}{ }^{2-}$ & 70 & 48 & 37 & 48 & 47 & 19 & 71 & 14 & 51 & 48 \\
\hline $\mathrm{Cl}$ - & & & 2,354 & & & & & & & \\
\hline$F-$ & 2.6 & 5.1 & 5.3 & 4.8 & 4.7 & .6 & 4.2 & .9 & 6.7 & 5.4 \\
\hline $\mathrm{SiO}_{2}$ & & & 81 & & & & & & & \\
\hline
\end{tabular}

All concentrations are in $\mathrm{mg} / 1$ except for SpC in micromhos and temperature in degrees centigrade. Hardness and alkalinity are in mg/l as $\mathrm{CaCO}_{3}$. 


\section{Seismicity}

The Raft River Valley is bordered by the seismically active Basin and Range province, the Intermountain Seismic belt, and the aseismic Snake River Plain. Although the valley is located in a seismic risk zone 3 , indicating a long-term hazard for seismic events of Richter magnitude (m) $\geq 4$, its historical and present aseismic character is more closely related to the inactive Snake River Plain.

Historical data indicate no high-magnitude events recorded within Cassia County, ${ }^{3}$ and only three significant events (magnitudes 5.1 in 1934, 5.4 in 1937, and 1.5 in 1973) located 30 to $50 \mathrm{~km}$ west of the Raft River KGRA, near the border between Cassia County, Idaho and Utah. ${ }^{4,5} \mathrm{~A}$ 90-day microseismic survey conducted in 1974 recorded seven events, all less than $0.2 \mathrm{M}$, with epicenters located within $17 \mathrm{~km}$ of the geothermal site. ${ }^{6}$

The possibility for induced seismic activity from local pressure changes in the geothermal reservoir during production and injection prompts the need for a continuing microseismic study at Raft River. Baseline data are currently being collected from a three-station network surrounding the KGRA (Figure 3). These data will be compared to high-volume production data to determine possible induced seismicity.

The permanent seismic network has been operational since mid-May, 1980. Sites with the least amount of background noise were selected using portable seismometers. Each field site consists of a Geotech S-500 seismometer, a Sprengnether VCO-amplifier and a Monitron radio. Mixed seismic signals and time are recorded on a Bell and Howell VR-3700B tape recorder. An identical tape recorder plays back through Develco discriminators onto an 8-channel Gould Brush chart recorder.

The FM-coded signals are transmitted from each station to a relay in the Black Pine Mountains, where they are mixed, and transmitted to a relay south of the Great Salt Lake. This relay transmits them to the University 


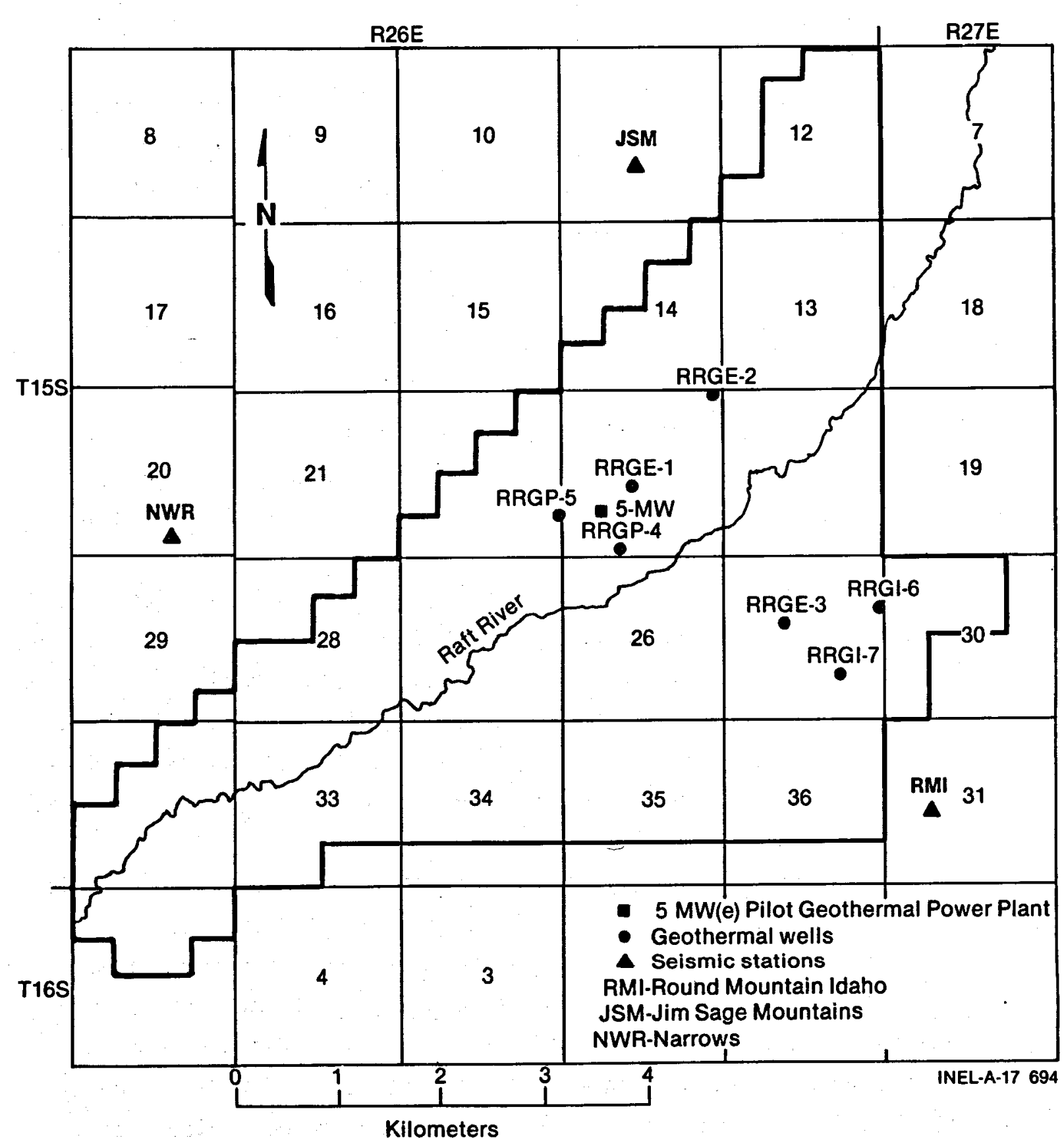

Figure 3. Location of seismic stations. 
of Utah Research Institute, Earth Science Laboratory recording facility where they. are recorded on magnetic tape. 7

Regional and teleseismic (worldwide, greater than 5M) events have been recorded at the Raft River monitors, however the epicenters have not been located. Several local events (within $65 \mathrm{~km}$ ) have been recorded at the Raft River array; ${ }^{8}$ however, no events were recorded which can be related to the geothermal system.

\section{Meteorology}

The weather station east of RRGE-2 is designed to monitor wind velocity and direction, precipitation, ambient air temperature, and dewpoint temperature. These data are required by many of the continuing environmental monitoring programs since meterology has a direct effect on most aspects of the environment. The station automatically samples once every six minutes and the data are transmitted to the National Oceanic and Atmospher ic Administration (NOAA) computers at the Idaho National

Engineering Laboratory (INEL). Due to problems which developed in the data transmission and receiving system, only a portion of the data was collected during 1980. Modifications in the software have corrected these problems.

A wind rose based on hourly Raft River data collected during 1980 is presented in Figure 4. Thirteen percent of the data for the year are missing. The Malta weather station, located near the geothermal site, provides comparable precipitation and temperature data. Average monthly precipitation for Malta is presented in Figure 5 and indicates that the spring was unusualiy wet. Average monthly temperatures for Malta are presented in Figure 6 and were normal when compared to historical data. The highest temperature for the year recorded at Malta was $37.8^{\circ} \mathrm{C}$ on July 28 and the low was $-27.8^{\circ} \mathrm{C}$ recorded on January 30 . 


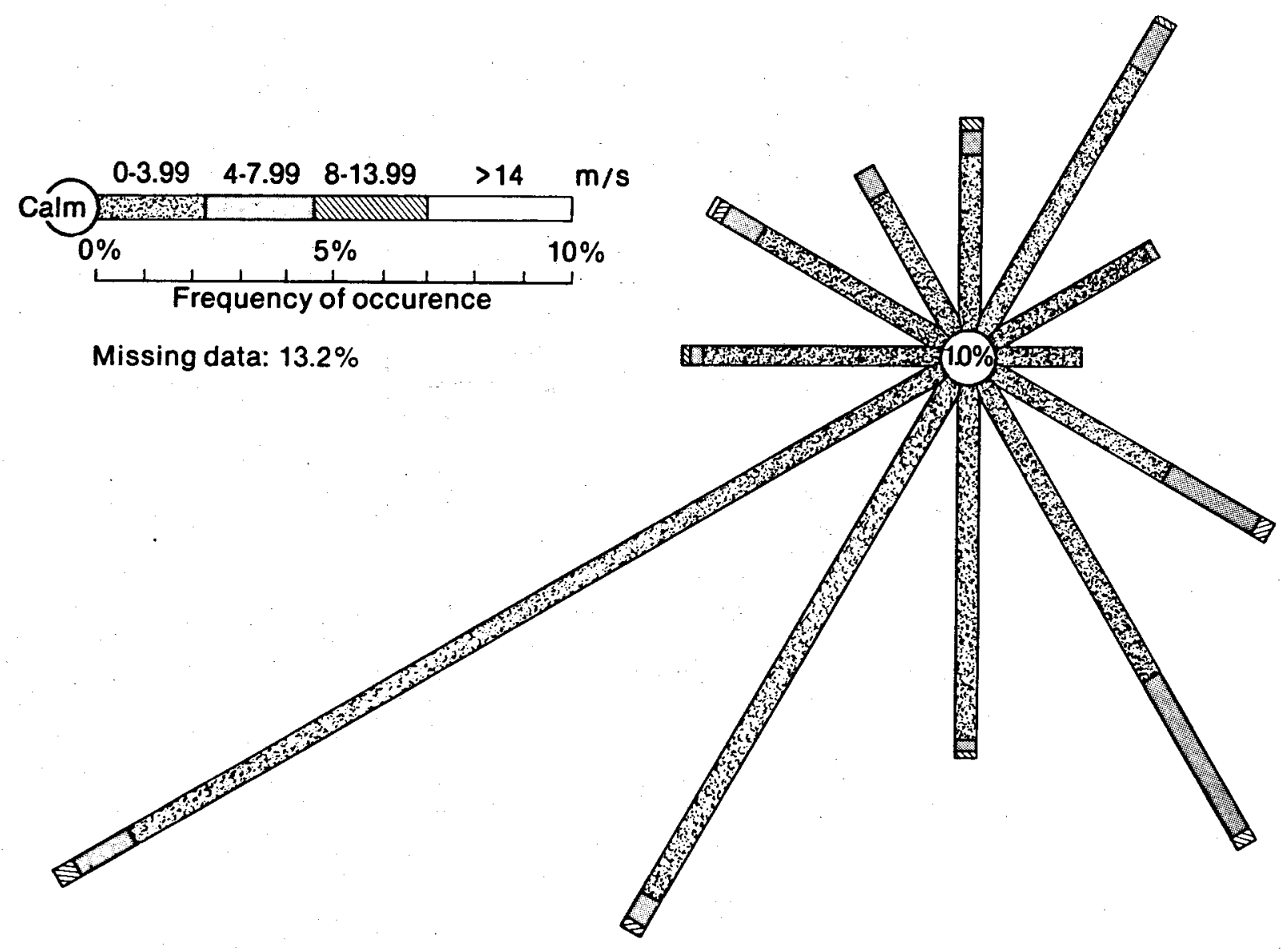

INEL-A-17 693

Figure 4. Raft River 1980 wind rose. 


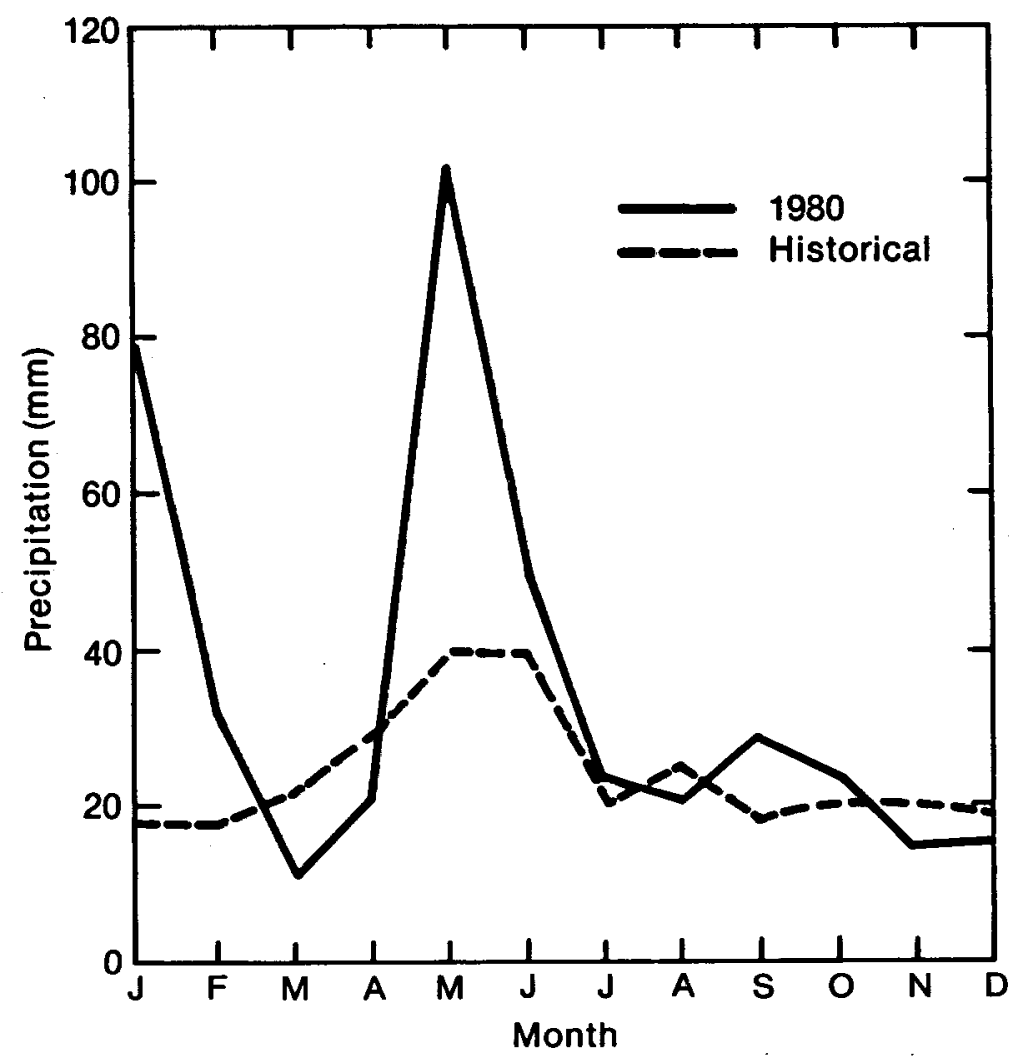

Figure 5. Raft River (Malta) 1980 average monthly precipitation.

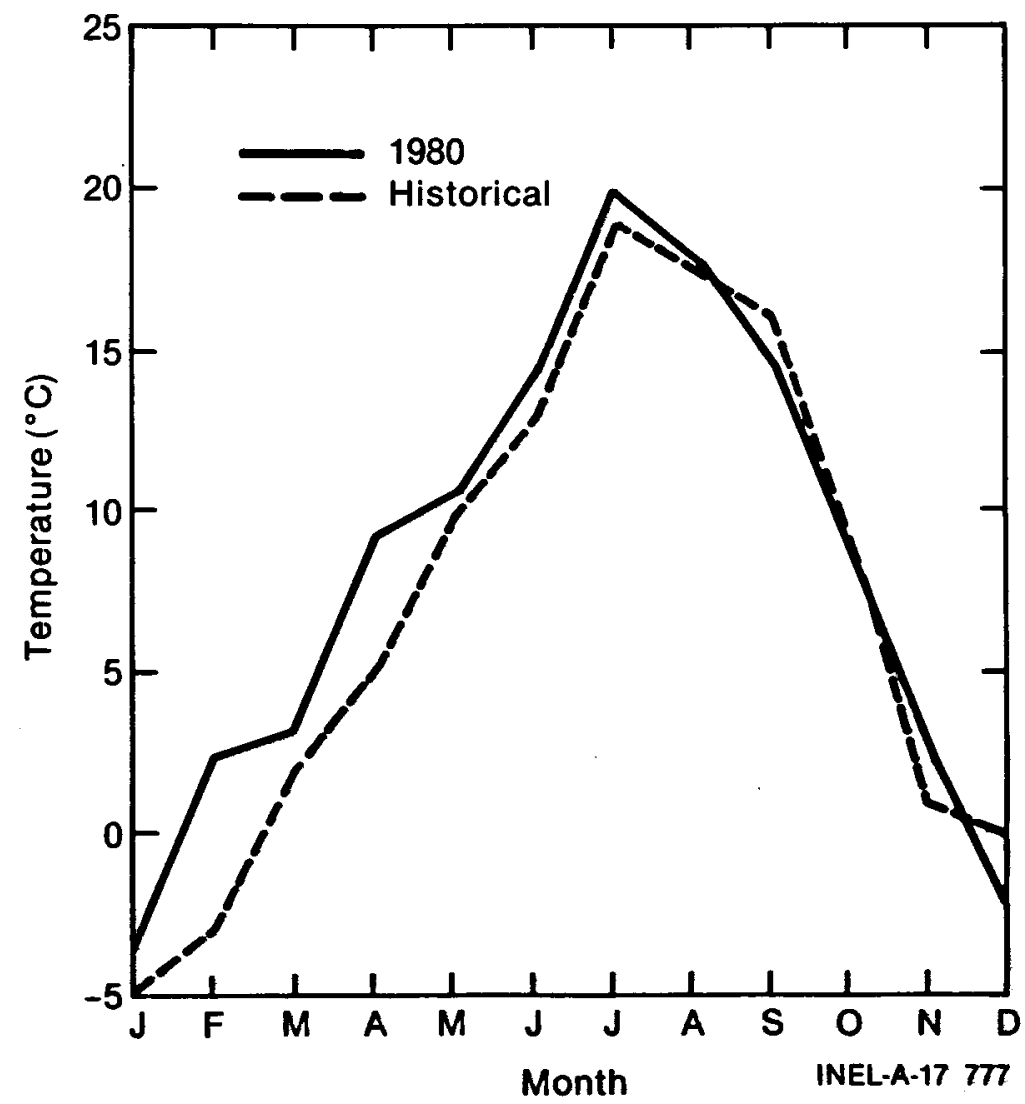

Figure 6. Raft River (Malta) 1980 average monthly temperatures. 


\section{Air Quality}

Introduction

The air quality monitoring program in the Raft River Valley is designed to collect baseline data and to identify the impacts of suspended particulates released due to geothermal development. The two principal sources of particulates expected in the Raft River Valley are cooling tower drift from the 5-MW(e) power plant and fugitive dust. Cooling tower emissions will depend upon the type of water treatment (chromate or phosphate) used in the cooling system. Hydrogen sulfide $\left(\mathrm{H}_{2} \mathrm{~S}\right)$ and other noncondensable gases are not expected to be a problem because previous studies $^{9}$ at the Raft River site have shown that very low concentrations of these gases are emitted from the geothermal fluids (Table 2).

Methods

The Raft River monitoring program is designed to obtain data regarding size distribution, composition, quality, and dispersion characteristics of particulates. The monitoring network consists of four stations strategically located around the geothermal power plant. These stations are located to minimize the effects from road traffic, construction, field plowing or other activities that generate substantial amounts of dust. Prevailing winds are usually from southwest of the site. Three stations are located downwind from the power plant and the control station is upwind in the Narrows (Figure 7). When winds are from the east, the Narrows station will serve as a monitoring station.

Each monitoring station is equipped with a hi-volume and low-volume particulate sampler. The hi-vol sampler collects total suspended particulates (TSP) samples by drawing ambient air at a rate of 68 to $102 \mathrm{~m}^{3} / \mathrm{hr}$ through a glass-fiber filter. Each sampler is equipped with a flow recorder to document the flow rate and duration of sampling so that accurate TSP concentrations can be determined. The low-vol sampler 
TABLE 2. 24-HOUR AVERAGE CONCENTRATION OF ENVIRONMENTAL POLLUTANTS NEAR RRGE-2, RAFT RIVER

\begin{tabular}{|c|c|c|c|c|}
\hline Date & $\begin{array}{c}\mathrm{H}_{2} \mathrm{~S} \\
\mu \mathrm{g} / \mathrm{m}^{3}\end{array}$ & $\begin{array}{c}\mathrm{SO}_{2} \\
\mu \mathrm{g} / \mathrm{m}^{3} \\
\end{array}$ & $\begin{array}{c}\mathrm{NO}_{2} \\
\mu \mathrm{g} / \mathrm{m}^{3} \\
\end{array}$ & $\begin{array}{r}0_{3} \\
\mu \mathrm{g} / \mathrm{m}^{3} \\
\end{array}$ \\
\hline $12(17-18) 76$ & $19.3 \pm 3.9$ & $12.5 \pm 1.3$ & 3.2 & 58.9 \\
\hline $12(22-23) 76$ & $11.9 \pm 2.4$ & $13.5 \pm 1.4$ & 6.1 & 61.9 \\
\hline $12(29-30) 76$ & $3.3 \pm .7$ & $7.8 \pm .8$ & 3.6 & 37.9 \\
\hline $11(3-4) 77$ & $7.8 \pm 1.6$ & $2.1 \pm .2$ & 3.0 & 66.4 \\
\hline
\end{tabular}




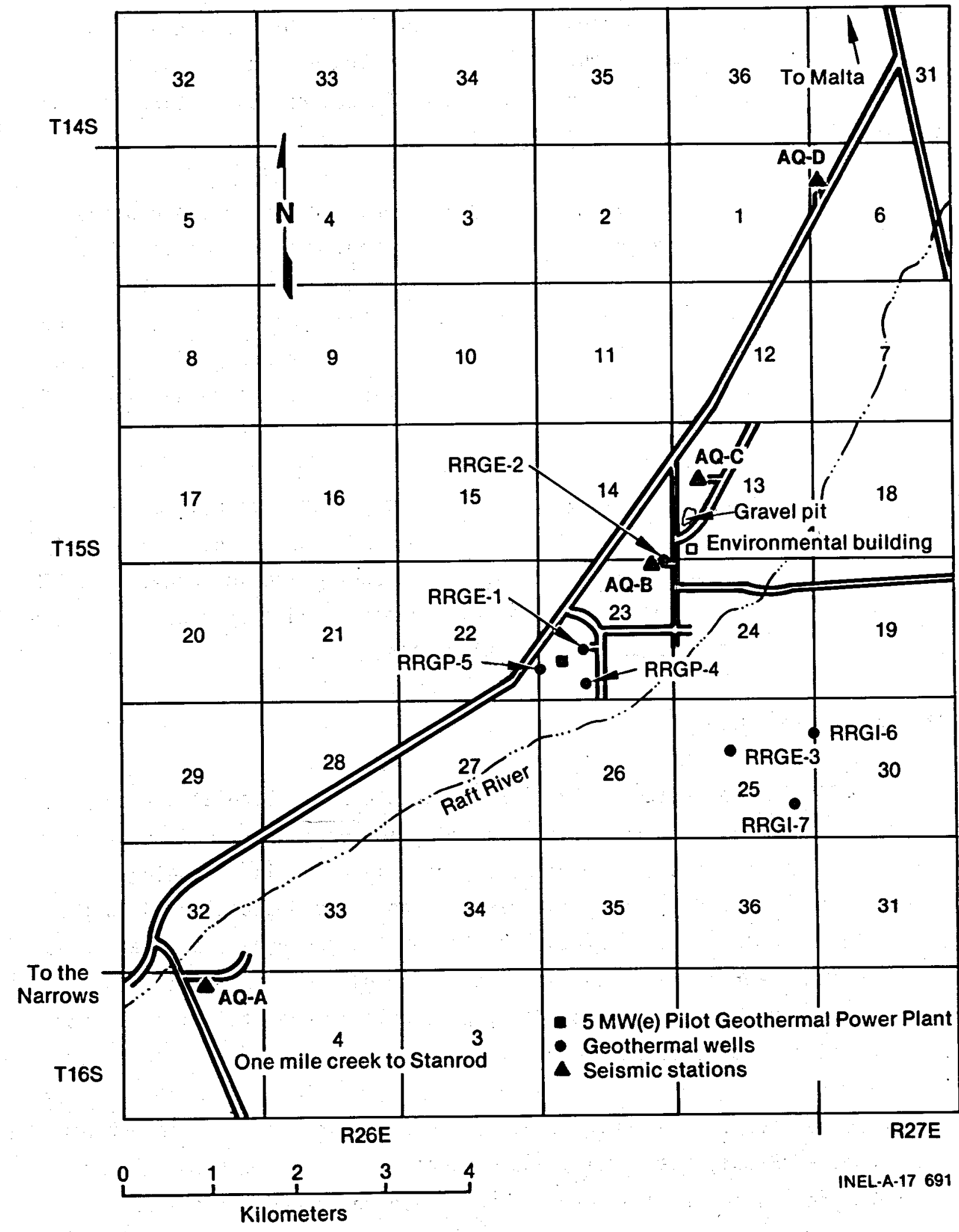

Figure 7. Location of air quality monitoring stations. 
collects suspended particulates on a membrane filter by drawing 1.7 to $6.8 \mathrm{~m}^{3} / \mathrm{hr}$ of ambient air through the filter membrane. These baseline data will meet the Prevention of Significant Deterioration requirements of the 1977 amendments to the Clean Air Act.

Both gravimetric and atomic absorption ( $A A$ ) analyses are performed on the hi-vol filters. The gravimetric analysis provides information on the TSP concentration; the AA quaritifies specific chemical constituents. The $A A$ analysis is used to characterize particulate emissions from the cooling tower, particularly chromates. Scanning electron microscopy (SEM) of the low-vol filters will be performed and will determine the size and shape of the suspended particles.

The monitoring stations operate every 6 days for a 24-hour period. This sampling frequency of five times each month measures the mean annual particulate concentration with at least a $90 \%$ confidence interval. The TSP concentrations are correlated with hourly average wind histories during the sample day to identify sources of particulates.

Results and Discussion

Sampling began September 28, 1980. Background particulates are generated primarily by construction, farming and vehicular traffic at or near the geothermal site. The highest particulate levels are being observed at Station $D$, which is nearest to the unpaved access road to the site. The lowest levels are found at Station $A$ where vehicular traffic is at a minimum. Particulate concentrations are related to wind speed and direction, being higher on windy days, particularly when the wind is from the direction of an unpaved road.

A summary of TSP concentrations is presented in Table 3 . In October (including $9 / 28 / 80$ ), the particulate concentrations ranged from a low of $1.7 \mathrm{\mu g} / \mathrm{m}^{3}$ to a high of $70.6 \mu \mathrm{g} / \mathrm{m}^{3}$, with an average concentration of $29 \mu \mathrm{g} / \mathrm{m}^{3}$. The particulate concentrations during the five sampling days in November ranged from a low of $6.2 \mu \mathrm{g} / \mathrm{m}^{3}$ to a high of $17.4 \mu \mathrm{g} / \mathrm{m}^{3}$ with 
an average concentration of $10.6 \mu \mathrm{g} / \mathrm{m}^{3}$ In December, the particulate concentrations ranged from undetectable to $36.2 \mu \mathrm{g} / \mathrm{m}^{3}$, averaging $12.4 \mathrm{\mu g} / \mathrm{m}^{3}$. These levels are far below the maximum particulate concentrations of $260 \mu \mathrm{g} / \mathrm{m}^{3}$ (annual mean of $75 \mu \mathrm{g} / \mathrm{m}^{3}$ ) and $150 \mu \mathrm{g} / \mathrm{m}^{3}$ (annual mean of $60 \mu \mathrm{g} / \mathrm{m}^{3}$ ) allowed under the primary and secondary standards, respectively, of the National Ambient Air Quality Standards. Chromate $\left(\mathrm{CrO}_{4}\right)$ concentrations were below the lower detectable limit of $0.01 \mu \mathrm{g} / \mathrm{m}^{3}$ on all sample days.

The air quality monitoring program is providing quantitative data on the background particulate levels in the Raft River Valley. The network will provide data on cooling tower emissions after start-up of the power plant. These data will be incorporated into a model designed to predict potential long-term impacts of the 5-MW(e) pilot plant on ambient air quality. 
TABLE 3. AVERAGE TOTAL SUSPENDEP PARTICULATES (TSP) CONCENTRATIONS
$(9 / 28 / 80$ to $12 / 27 / 80)(0,11,12$

$\begin{array}{cccc}\text { Site } & \begin{array}{l}\text { Average Flow } \\ \text { Rate_(cmh) }\end{array} & \frac{\text { TSP Concentration }\left(\mu \mathrm{g} / \mathrm{m}^{3}\right)}{(\text { average }} & \frac{(\text { range })}{\left(0^{\mathrm{a}}-29.3\right)} \\ \text { A } & 83.3 & 12.9 & (3.7-70.6) \\ \text { B } & 83.3 & 19.9 & (2.9-41.7) \\ \text { C } & 89.2 & 16.8 & (4.7-59.8) \\ \text { D } & 95.5 & 22.2 & \end{array}$

a. Below the lower detection limit. 
Effective environmental management requires an understanding of the diversity and population interactions of the biotic community. At the Raft River Valley, baseline data on the flora and fauna have been collected. The habitat of the valley is classified as a cold-desert ecosystem. The vegetation communities are dominated by a mixture of sagebrush (Artemisa), greasewood (Sarcobatus), rabbitbrush (Chrysothamnus), bunch grass (Agropyron), and other low-growing shrubs and forbs. The wildlife of the region are adapted to and dependent upon this fragile desert ecosystem.

Ecological studies conducted at the geothermal site during 1980 include a survey of the plant and aquatic communities, and raptor, rabbit and songbird studies. By understanding the ecosystem structure and function, and adjusting human activities to minimize ecological impacts, an equitable and intelligent use of the area resources can be achieved.

\section{Plant Ecology}

\section{Introduction}

Disturbance of the natural vegetation due to physical alteration of the site (pipelines, well pads, roads, etc.) is an easily diagnosed impact associated with construction activities. The effects of effluents on the vegetation and soils are more subtle and require adequate baseline data to differentiate geothermal-related impacts from natural variation within the community. A 4-year study of the soil and vegetation of the Raft River Valley was completed in 1980. ${ }^{13}$ This study provides a quantitative and statistical basis for interpreting baseline conditions and the vegetational response to variations in climate, soils, and other environmental factors.

\section{Methods}

Twenty-three permanent plots, representing each major vegetation and soil type, were established in a radiating pattern from RRGE-1, RRGE-2, and 
RRGE-3 (Figure 8 ). These plots have a radius of $8 \mathrm{~m}$ and an area of 0.02 hectare (ha). The plots were divided among 9 groups of vegetation as foll lows:
6 greasewood
4 sagebrush-greasewood
4 sagebrush
2 river streamside
1 hot water streamside
2 salt bush
2 shadscale
1 grass
1 winterfat

Twenty-five $1-m^{2}$ quadrats were sampled within each permanent plot. All species occurring in each quadrat were recorded. Total litter, rock, bare soil, and living cover were estimated. Living cover data included relative percent cover of shrubs, grasses, perennial forbs, annuals and cryptogams.

Climatic data were collected on twelve of the plots, and included precipitation, maximum and minimum temperatures, and soil temperatures at $30-\mathrm{cm}$ depths. The upper $15 \mathrm{~cm}$ of soil was sampled with a composite sample from 10 quadrats in each plot, and the surface and $A$ and $B$ horizons were sampled in selected plots.

\section{Results and Discussion}

Shrub frequency [common species include big sagebrush (Artemisia tridentata) and greasewood (Sarcobatus vermiculatus)] remained similar from year to year (1976-20.8\%, 1977-21.8\%, 1978-20.4\%, and 1979-18.0\%). Perennial grasses [e.g. bunch grasses (Agropryon spp) and bromegrass (Bromus sp)] responded to the dry year of 1977 with an increase in relative frequency from $17.3 \%$ cover in 1976 to $24.6 \%$ in 1977 . As perennial grass frequency increased, perennial forbs [e.g. asters (Aster $s p$ ) and prickly 


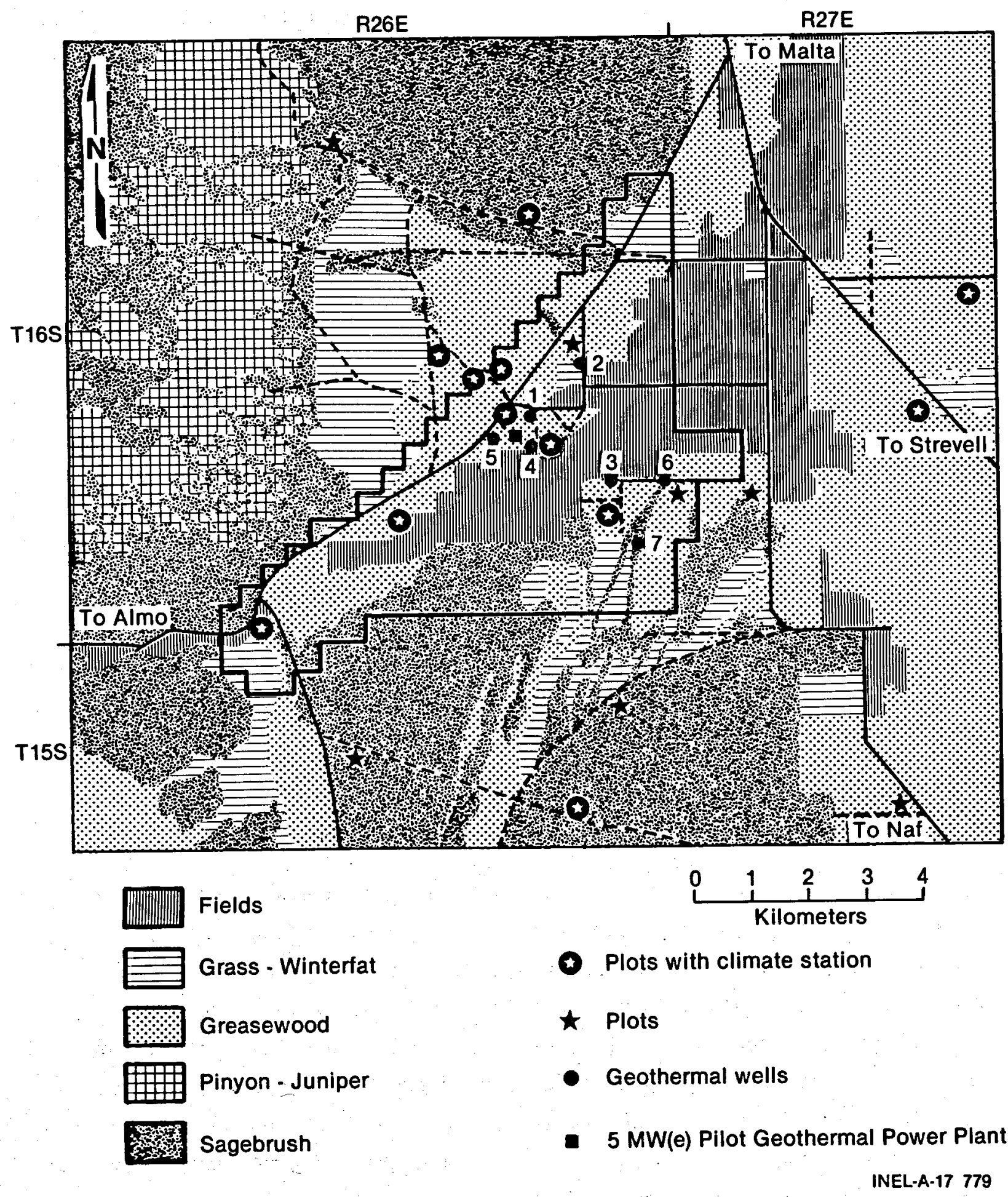

Figure 8. Location of permanent vegetation plots. 
pear cactus (Opuntia sp)] and annuals [e.g. cheat grass (Bromus tectorum) and halogeton (Halogeton glomeratus)] decreased. Forbs decreased from $17.4 \%$ total cover in 1976 to $11.0 \%$ in 1977 and then increased to $15.1 \%$ and $14.7 \%$ in 1978 and 1979, respectively. Annuals declined in frequency from an average of $84.9 \%$ in 1976 to $67.0 \%$ in 1977 and then recovered to $73.1 \%$ in 1978 and $99.3 \%$ in 1979. These trends reflect the effect of a dry year in 1977 followed by wetter years in 1978 and 1979. A partial recovery of annuals and perennial forbs occurred in 1978 followed by prolific growth in 1979. It is hypothesized that after a dry period, a greater amount of space is available due to dieback of the shrubs. New plant growth and proliferation begins when seeds germinate after the return of optimum moisture conditions, resulting in a "pulse-like" increase in plant density. This pulse is also demonstrated in the number of species per quadrat. The average number of species sampled per quadrat was 75 in 1976, 73 in 1977, 74 in 1978, and 87 in 1979. A total of 105 species were identified over the four years of the study.

Sixteen cover characteristics were used to conduct correlation tests with various environmental parameters. Significant positive correlations exist between plant diversity, and soil sand content and salinity. Diversity increases on sandier soils with higher salinity. Plants grow well on these sites because they are salt tolerant, and because the soil moisture is usually higher. As would be expected, the plant density is greatest where moisture stress is lowest.

A multiple correlation test using trivariate data was run for the total number of vascular species per stand, and the independent soil variables of percent sand and salinity (electrical conductivity $E C_{e}$ ). The multiple correlation coefficient $(r)$ was 0.94 , giving a multiple coefficient of determination $\left(r^{2}\right)$ of 0.89 . This indicates that $89 \%$ of the variability in total cover is accounted for by the variables percent sand and salinity $\left(E C_{e}\right)$. The regression equation is based on the observed values and can be used in predicting the effect on total cover of increasing salinity or percent of sand. 
Shrubs correlate positively with factors such as percent rock, percent clay, organic carbon concentration, and percent nitrogen. The more ephemeral plants, such as annuals and some perennial forbs, correlate at much higher levels with soil texture, salinity, and pH factors.

A multiple correlation and regression test was run using total percent cover as the dependent variable, and percent soil fines and soil pH as the independent variables. The resulting multiple correlation value of 0.95 indicates that interaction of these three variables is high.

This research provides baseline data on the vegetation communities of the Raft River geothermal site, and indicates that variations in plant community composition occur from year to year. If the proposed developments for the region are realized, it is probable that a vegetation response may occur which will be much more dramatic than those fluctuations observed during this study. In this case, the sensitive perennial forbs and annuals would serve as good indicator organisms by clustering differently than previously observed. Thus, potential changes in the plant ecology of the region could be quickly identified.

\section{Aquatic Ecology}

\section{Introduction}

The Raft River is the only perennial stream in the valley and is, therefore, an important part of the area's ecosystem. The potential impact on stream biota from an accidental spill of geothermal water is an important concern. Predicting the impact of such a disturbance is difficult without first establishing the baseline ecology of the stream. A two-year study of the aquatic ecology of the Raft River was completed in 1980. 14 The objectives of the study were: 1) to characterize the faunal and floral communities of the river, 2) to assess the physical characteristics of various aquatic habitat types near the geothermal site, and 3 ) to establish baseline information concerning community structure and population dynamics. 
Methods

Three stations were established on the Raft River near the geothermal facility (Figure 9). Station A was $1.2 \mathrm{~km}$. downstream from the main geothermal facility (at RRGE-1), Station B was directly south of RRGP-4, and Station $C$ was $6.5 \mathrm{~km}$ upstream from the geothermal site. Station $C$, therefore, would not be affected by geothermal spills.

Two methods were used for fish collecting. Electroshocking, used originally, resulted in unacceptable levels of fish mortality. In July, 1979, the mode of sampling was changed to seining. At each station, a 75-m section of the river was seined twice on consecutive days. The fish captured on the first seining pass were measured, weighed, and marked using a caudal-fin clip. The frequency of fish collected on the second seining pass was used in estimating the population density for each species. These data yielded a species list, the abundance of each species at each station, the size class distribution of each species, and the age structure of the larger fish species.

During each sampling period, 10 benthic samples at each station were collected to a depth of $10 \mathrm{~cm}$. Core samples were taken in those substrates where a coring device was operable; otherwise box samples were collected. The invertebrates in these samples were identified and censused to determine density and diversity. The sediments were separated and dried, and a size analysis was performed. The sediment-size fractions were weighed, and the weight frequencies converted to percents for between-sample comparisons.

Results and Discussion

Aquatic community structure is strongly influenced by physical factors. Stations $A$ and $C$ had the most similar substrate types, being composed of $56 \%$ and $51 \%$ rubble (particle size $>64 \mathrm{~mm}$ ) respectively, while Station B was only $29 \%$ rubble. Algal cover depended upon the amount of rubble for attachment, and the time of year. A seasonal trend occurred 


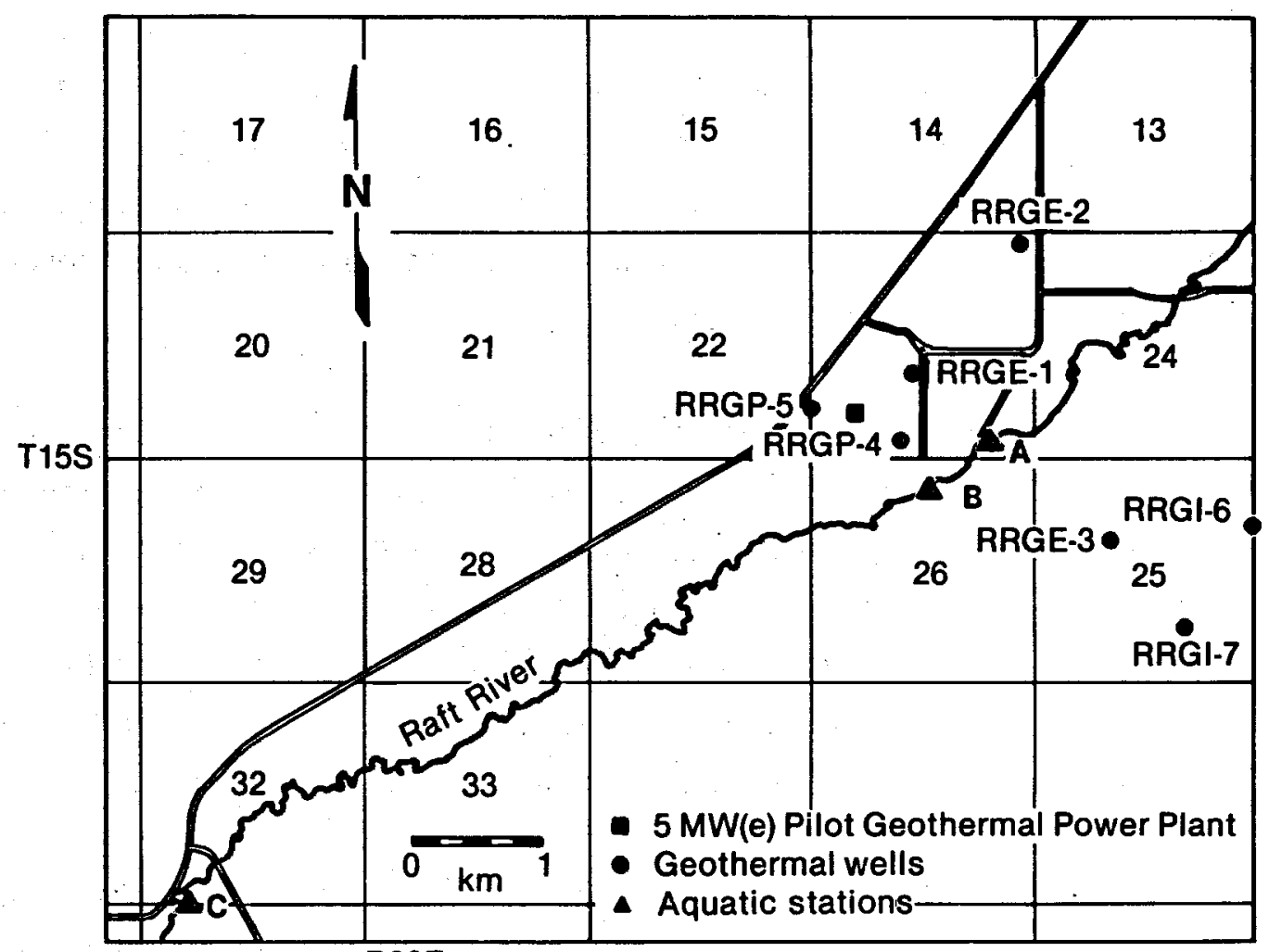

R26E

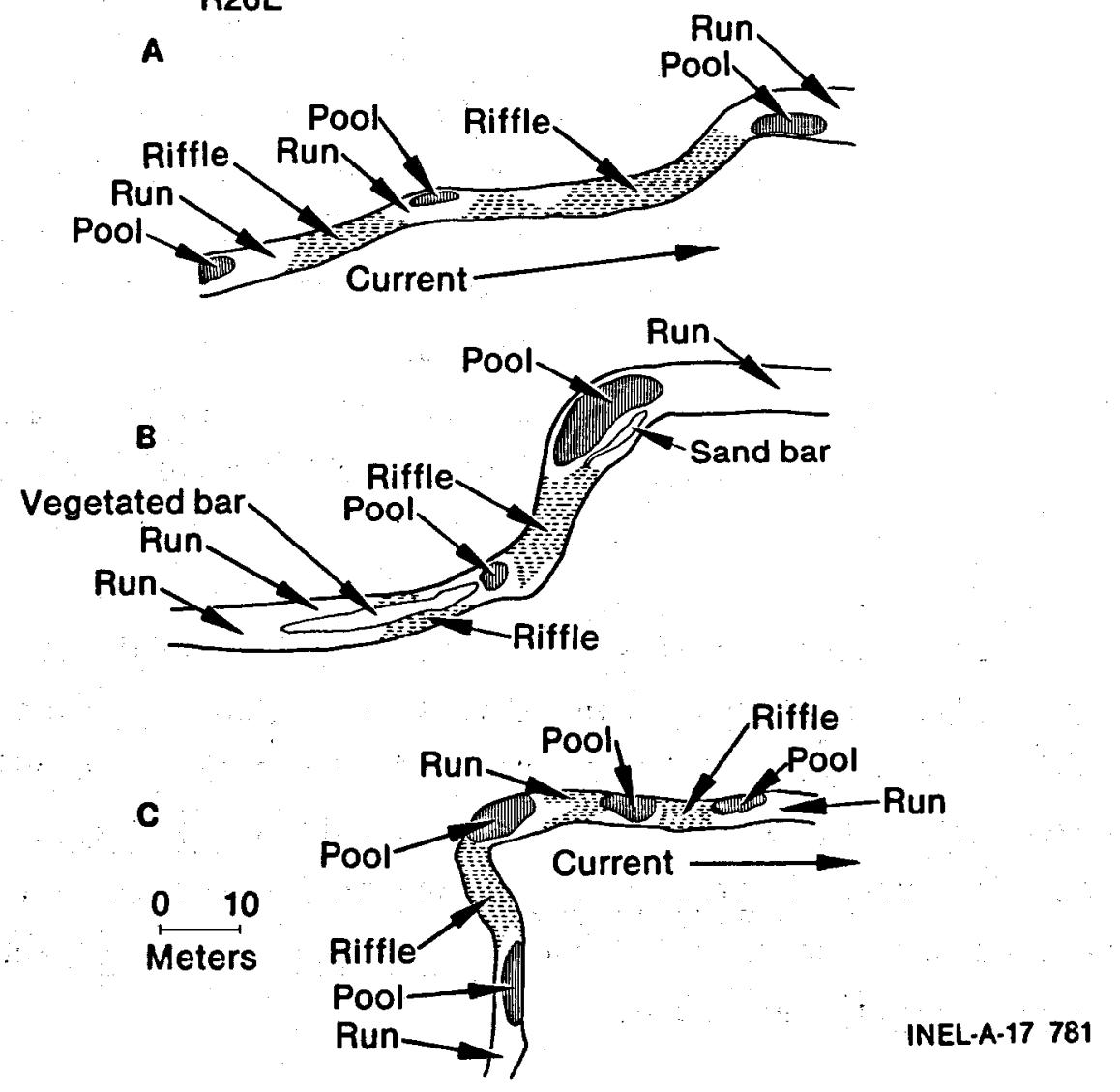

Figure 9. Map of aquatic stations on the Raft River. 
with low algal cover in the spring and increasing cover through the summer into September, with filamentous green algae becoming more dominant. The increase in algal cover was most rapid on the more stable rubble material collected in the box samplers. An algal colonization lag is apparent in the finer substrates collected in the core samples because these substrates are more susceptible to erosion.

Stations $A$ and $B$ had much greater fluctuations in water depth than Station $C$, being shallower in the summers and deeper in the winters. During sampling in November-December 1979, both Stations A and B were completely ice covered with $\geq 30 \mathrm{~cm}$ of ice and a 2 - to $5-\mathrm{cm}$ water space. This freezing phenomena creates a refuge for benthic invertebrates, but is selectively detrimental to large fish. Thus the importance of large pools for overwintering $f$ ish is increased at Stations $A$ and $B$.

Total dissolved solids (TDS) content increased downstream, with Station A having 2.3 times the TDS of Station $C$ and Station B having 1.8 times the TDS of Station C (Table 4). The overall TDS decreased from April to September. The higher TDS of Stations $A$ and $B$ is related to the presence of carbonates which cement the rubble and sediment matrix together, forming a hardpan in the riffle areas. Much of this precipitant is associated with the photosynthetic activities of epilithic crustose algae. The net result is that a more permanent stream bed is formed over the riffle areas. This hardpan protected Stations $A$ and $B$, leaving them unchanged during the spring flood in 1980, while Station C was completely restructured.

Seven species of fish, representing four families, were collected at the sampling stations during this study. Two Cyprinids, longnose dace (Rhinichthys cataractae) and redside shiner (Richardsonius balteatus), and one Catostomid, mountain sucker (Pantosteus platyrhynchus), were abundant. The Utah sucker (Catostomus ardens) and Piute sculpin (Cottus beldingi) were common, and speckled dace (Rhinichthys osculus) and cutthroat trout (Salmo clarki) were rare. 
TABLE 4. CONCENTRATIONS OF TOTAL DISSOLVED SOLIDS (TDS) AT THE RAFT RIVER SAMPLING STATIONS (in $\mathrm{mg} / \mathrm{l}$ )

\begin{tabular}{cccc}
\hline STATION & July 1979 & Sept. 1979 & Apri1 1980 \\
\hline A & $-\ldots$ & 1105.1 & 745.1 \\
B & 775.1 & 855.8 & 808.0 \\
C & $-\ldots$ & 474.3 & 733.0 \\
\hline
\end{tabular}


Catchability is the probability of an individual fish being captured. For example, a numerical value of 0.5 indicates a $50 \%$ probability that a given marked fish will be recaptured. The catchability data are presented in Table 5 and reflect the bias introduced by the different sampling techniques. Electroshocking is biased against redside shiners and selectively favors the suckers and sculpins. This is because the larger size of the suckers makes them more susceptible to electric fields. Seining proved to be a better technique, except in riffles where the large substrate particles often entangled the net and allowed some fish to escape.

During the electroshocking in November 1978, Station C was divided into four sections based on habitat type. Diversity was lowest in the riffles and highest in the large pool. This is opposite to the relationship expected for benthic organisms but can be explained by diel movements. The fish may move out of the pool at night to forage in the more productive shallows, especially the riffles. The presence of predatory birds in the area would discourage daylight feeding in these shallows. The fish surveys conducted during the day reveal preferred refuge areas rather than a full diel habitat preference.

An examination of fish density over time reflects trends in the fish population (Table 6). Redside shiners, mountain suckers and Utah suckers show a progressive shift in density distribution between the three stations, with a definite decrease in the downstream station (A) in September. These fish migrate upstream, perhaps as a response to seasonal changes such as decreasing flow rates, declining water temperatures, or increasing size of the fish. Migrating upstream in the fall may increase the chance of surviving the winter, particularly if the downstream stations freeze as observed in December 1979.

Another trend observed from the density data is a general population increase from July to September. Much of this increase is a result of greater catchability of the young-of-the-year longnose dace as they get larger. 
TABLE 5. CATCHABILITY OF FISH SPECIES IN RAFT RIVER

\begin{tabular}{|c|c|c|c|c|c|c|c|c|c|c|c|}
\hline \multirow[b]{3}{*}{ Station } & \multicolumn{4}{|c|}{ Electroshocking } & \multicolumn{7}{|c|}{ Seining } \\
\hline & \multirow[b]{2}{*}{$c-1$} & \multicolumn{3}{|c|}{$11 / 78$} & \multicolumn{3}{|c|}{$7 / 79$} & \multicolumn{3}{|c|}{$9 / 79$} & \multirow{2}{*}{$\frac{12 / 79}{c}$} \\
\hline & & $\underline{\mathrm{C}-2}$ & $\underline{c-3}$ & $\underline{C-4}$ & A & B & $\underline{c}$ & $A$ & $\underline{B}$ & $\underline{C}$ & \\
\hline \multicolumn{12}{|l|}{ Species } \\
\hline Longnose dace & .22 & $-\cdots$ & .17 & .38 & .57 & .38 & .11 & --- & .65 & .24 & .16 \\
\hline Redside shiner & -- & --- & --- & -- & .88 & .68 & .68 & --- & .89 & .25 & .50 \\
\hline Mountain sucker & -- & .84 & .74 & .32 & .20 & .57 & .75 & .28 & .69 & $\cdots$ & .17 \\
\hline Utah sucker & -- & --- & $\cdots$ & .67 & .58 & .92 & .83 & $\cdots$ & $\cdots$ & .65 & .33 \\
\hline Piute sculpin & .60 & .89 & .00 & --- & $\cdots$ & -- & .70 & --- & $\cdots$ & -- & -- \\
\hline Total & .52 & .88 & .30 & .20 & .70 & .57 & .65 & --- & .67 & --- & .19 \\
\hline
\end{tabular}


TABLE 6. ESTIMATED DENSITIES OF THE FISH POPULATION USING SEINING DURING 1979

\begin{tabular}{|c|c|c|c|c|c|c|c|c|c|c|c|c|c|c|c|}
\hline \multirow[b]{3}{*}{ SPECIES } & \multicolumn{6}{|c|}{ July } & \multicolumn{6}{|c|}{ September } & \multicolumn{3}{|c|}{ December } \\
\hline & \multicolumn{2}{|c|}{ A } & \multicolumn{2}{|c|}{ B } & \multicolumn{2}{|c|}{ c } & \multicolumn{2}{|c|}{ A } & \multicolumn{2}{|c|}{$B$} & \multicolumn{2}{|c|}{$c$} & \multirow[t]{2}{*}{ A } & \multirow[t]{2}{*}{$B$} & \multirow{2}{*}{$\frac{c}{\text { (II) }}$} \\
\hline & (\#) & (\%) & (\#) & (q) & (\#) & (\%) & (II) & (q) & (II) & $(q)$ & (H) & (b) & & & \\
\hline Longnose dace & 301 & 35 & 299 & 35 & 261 & 30 & 466 & 38 & 418 & 33 & 385 & 29 & $\mathbf{F}$ & $\mathbf{F}$ & 192 \\
\hline Redside shiner & 163 & 26 & 162 & 27 & 266 & 45 & 15 & 4 & 113 & 29 & 264 & 67 & $R$ & $R$ & 12 \\
\hline Mountain sucker & 25 & 9 & 24 & 9 & 227 & 82 & 5 & 1 & 94 & 20 & 367 & 79 & 0 & 0 & 217 \\
\hline Utah sucker & 21 & 23 & 44 & 47 & 28 & 30 & 0 & 0 & 30 & 46 & 35 & 54 & 2 & 2 & 9 \\
\hline Piute sculpin & 2 & 8 & $8 c$ & 33 & 14 & 59 & 6 & 11 & $19 c$ & 35 & $29 c$ & 54 & $\mathbf{E}$ & $\mathbf{E}$ & $11^{b}$ \\
\hline Total fisha & 477 & - & 490 & - & 750 & - & 554 & - & 674 & - & 1080 & - & $\mathbf{N}$ & N & 441 \\
\hline
\end{tabular}

a. Values based on independent species estimates--they will not necessarily sum to the total value.

b. Estimates based on total fish minus the sum of all other fish except the sculpin.

c. Estimates based on the total number of fish collected. 
The hypothesis that some species of fish migrate upstream in late summer or early fall is further supported by a cluster analys is of the stations based on the coefficient of determination $\left(r^{2}\right)$. Samples from Stations $A$ and $B$ always cluster together at the $80 \%$ similarity level, while samples from the combined $C$ stations are not similar to each other. This indicates a temporal change in the fish community structure at $C$, while Stations $A$ and $B$ do not have the same trend. As the Utah and mountain suckers and the redside shiners migrate upstream, the age and species structure of the population remains the same at the downstream stations, thus maintaining a high correlation over time. However, Station $C$ is dominated by larger fish, averaging 50\% larger (range $17 \%$ to $88 \%$ ) than. those at Stations $A$ and $B$ (with the exception of the Piute sculpin). With the upstream movement of small fish, the average length of fish at Station $C$ decreases. Thus the similarity of Station $C$ with itself changes over time, and becomes slightly more similar to Stations $A$ and $B$. It is interesting to note that Station $C$ in November 1978 is the most dissimilar and further supports the hypothes is that electroshocking introduces a bias into the data.

The diversity and evenness of sediments from all stations appeared to be very similar. A cluster analys is of the sediment data was run on the average composition frequency from each station on each date and collapsed to the $65 \%$ similarity value. It was then apparent that Station C displayed the greatest temporal diversity, followed by Station B. Station C did not have the same carbonate precipitation in the riffles that encrusted and stabilized Stations $A$ and $B$, and would be expected to undergo seasonal changes in sorting and siltation. Station $B$ had fewer cemented riffles than Station $A$ and was more variable.

Forty-eight invertebrate genera were collected from the three stations and from other specialized habitats. The 0ligochaeta and Chironomidae were not identified to the generic level. Cluster analys is of the benthic communities reveals that there is very little difference between sites on a particular date but all sites respond to seasonal changes. 
The invertebrates were separated into functional groups (Table 7). Collectors dominate throughout the year and are most abundant at Stations $A$ and $C$. Collectors, grazers, and filter feeders reach their highest densities in the fall. Filter feeding density is much higher at Station $C$. This could reflect a decrease in the amount of detritus available downstream due to filter feeders or sedimentation in upstream sections. Shredders were relatively rare in all stations except Station C. Although a large shredder (Tipula) was collected in the process of seining Station $C$ in December 1979, they were not present in high enough frequencies to be collected in the benthic samples.

\section{Conclusions}

The ecology of the Raft River downstream of the geothermal site differs from the upstream portion and appears to be related to physical factors. Carbonate precipitation stabilizes the downstream riffles but does not occur at the upstream station. The more shallow gradient of the lower stations results in higher susceptibility to freezing and creates a much harsher winter environment. The fish population appears to adjust by migrating out of the downstream sections in the late summer and fall. For several species, the downstream areas act as a nursery ground for the young where competition is minimized. Whether these fish actively move downstream to spawn or if the young simply drift downstream is not known, but young-of-the-year fish were also collected at Station $C$. The invertebrate community is not as location-sensitive, but is influenced by seasonal factors. The invertebrates most likely respond to the pulsed nature of detritus, which is the predominant source of energy in stream systems regardless of its origin. All levels of detritivores would be similarly influenced. Grazers rely upon the growth of algae, which is also seasonal and is influenced by physical conditions such as amount of rubble and cementation.

The potential impact of a geothermal spill appears to be minimal, assuming the spill would be a single, short-lived perturbation. The invertebrate community would recover through colonization by drifting 
TABLE 7. DENSITY OF RAFT RIVER INVERTEBRATES BY FUNCTIOMAL GROUP (individuals/100 $\mathrm{cm}^{2}$ )

\begin{tabular}{|c|c|c|c|c|c|c|c|c|}
\hline Station & $\begin{array}{c}\text { Functional } \\
\text { Group }\end{array}$ & Total & $3 / 79$ & $4 / 79$ & $6 / 79$ & $\underline{7 / 79}$ & $9 / 79$ & $12 / 79$ \\
\hline$A$ & $\begin{array}{l}\text { Shredder } \\
\text { Collector } \\
\text { Grazer } \\
\text { Filterer } \\
\text { Piercer } \\
\text { Engulfer }\end{array}$ & $\begin{array}{r}0.18 \\
6783.35 \\
157.24 \\
314.02 \\
0.55 \\
15.62\end{array}$ & $\begin{array}{r}0.12 \\
47.73 \\
4.61 \\
2.26 \\
0.00 \\
0.06\end{array}$ & $\begin{array}{r}0.00 \\
21.23 \\
0.15 \\
0.91 \\
0.00 \\
0.00\end{array}$ & $\begin{array}{r}0.00 \\
768.21 \\
17.27 \\
0.77 \\
0.00 \\
0.03\end{array}$ & $\begin{array}{r}0.03 \\
522.70 \\
23.76 \\
16.50 \\
0.00 \\
0.09\end{array}$ & $\begin{array}{r}0.00 \\
4356.88 \\
103.62 \\
269.69 \\
0.00 \\
14.56\end{array}$ & $\begin{array}{r}0.03 \\
466.60 \\
7.83 \\
23.89 \\
0.55 \\
0.88\end{array}$ \\
\hline B & $\begin{array}{l}\text { Shredder } \\
\text { Coll ector } \\
\text { Grazer } \\
\text { Filterer } \\
\text { Piercer } \\
\text { Engulfer }\end{array}$ & $\begin{array}{r}0.79 \\
3810.94 \\
82.61 \\
87.55 \\
0.00 \\
9.686\end{array}$ & $\begin{array}{r}0.09 \\
107.39 \\
2.47 \\
4.18 \\
0.00 \\
1.06\end{array}$ & $\begin{array}{r}0.12 \\
136.35 \\
1.22 \\
7.35 \\
0.00 \\
0.00\end{array}$ & $\begin{array}{r}0.00 \\
798.16 \\
3.40 \\
0.63 \\
0.00 \\
0.00\end{array}$ & $\begin{array}{r}0.00 \\
854.26 \\
6.07 \\
2.57 \\
0.00 \\
4.53\end{array}$ & $\begin{array}{r}0.59 \\
1372.22 \\
61.74 \\
64.44 \\
0.00 \\
2.156\end{array}$ & $\begin{array}{r}0.00 \\
542.56 \\
7.71 \\
8.38 \\
0.00 \\
1.94\end{array}$ \\
\hline C & $\begin{array}{l}\text { Shredder } \\
\text { Collector } \\
\text { Grazer } \\
\text { Filterer } \\
\text { Piercer } \\
\text { Engulfer }\end{array}$ & $\begin{array}{r}2.37 \\
5326.87 \\
134.74 \\
926.83 \\
0.00 \\
2.25\end{array}$ & $\begin{array}{r}0.61 \\
73.56 \\
3.42 \\
10.62 \\
0.00 \\
0.95\end{array}$ & $\begin{array}{r}0.61 \\
48.46 \\
5.89 \\
2.85 \\
0.00 \\
0.12\end{array}$ & $\begin{array}{c}0.00 \\
1187.65 \\
18.44 \\
7.40 \\
0.00 \\
0.28\end{array}$ & $\begin{array}{r}0.00 \\
435.71 \\
6.59 \\
2.42 \\
0.00 \\
0.15\end{array}$ & $\begin{array}{r}1.15 \\
2907.72 \\
66.01 \\
886.61 \\
0.00 \\
0.12\end{array}$ & $\begin{array}{r}0.00 \\
673.77 \\
34.39 \\
16.93 \\
0.00 \\
0.63\end{array}$ \\
\hline
\end{tabular}


organisms. While some immature fish would be lost, the entire juvenile class would not be eliminated since the young are also found in the upstream stations. The fish use the downstream areas as habitat for the offspring, but not as the sole refuge for the population's survival.

\section{Rabbits}

\section{Introduction}

Small mammals are an important part of the Great Bas in ecology because they are the major prey source for most large predators and are the principal herbivores of the region. A study of the rodent population was conducted during 1977 and 1978 and is summarized in the 1979 annual report for the Geothermal Environmental Program. 15

Rabb it censuses were begun in 1978 to provide prey data necessary for an analysis of the ferruginous hawk population. The black-tailed jackrabbit (Lepus californicus), pygmy rabbit (Brachylagus idahoensis) and mountain cottontail (Sylvilagus nuttalli) inhabit the valley. Emphas is during the 1980 research was placed on the black-tailed jackrabbit and pygmy rabbit. The cottontail, an abundant generalist throughout North America, was the least common of the three species and was 1 imited in distribution to riparian or moist habitat in the Raft River Valley. The black-tailed jackrabbit was studied because knowledge of the 8- to 11-year cyclic population is necessary to accurately assess the prey-dependent predator populations. The pygmy rabbit population was studied to determine the distribution of this uncommon species in the valley. Also, the health of the pygmy rabbit population may be a good indicator of subtle changes in the specific habitat required by this species, and could be useful as an environmental monitoring tool for the area.

Methods

Black-tailed Jackrabbit Census. Density estimates for the blacktailed jackrabbit population were determined by walking $1.6-\mathrm{km}$ transects 
through habitat types representative of the vegetation in the valley. Ten transects were run in early July during both 1978 and 1979 (Figure 10). The censuses coincided with the fledging period of ferruginous hawks. In 1980, the census frequency was increased to 15 transects and was run during March, July, and October. The census data were analyzed using the flushing distance equation of Hayne: ${ }^{16}$

$N_{T}=\frac{1}{2 L}\left(\frac{F_{i}}{d_{j}}+\frac{F_{2}}{d_{2}}+\ldots .+\frac{F_{n}}{d_{n}}\right)$

where

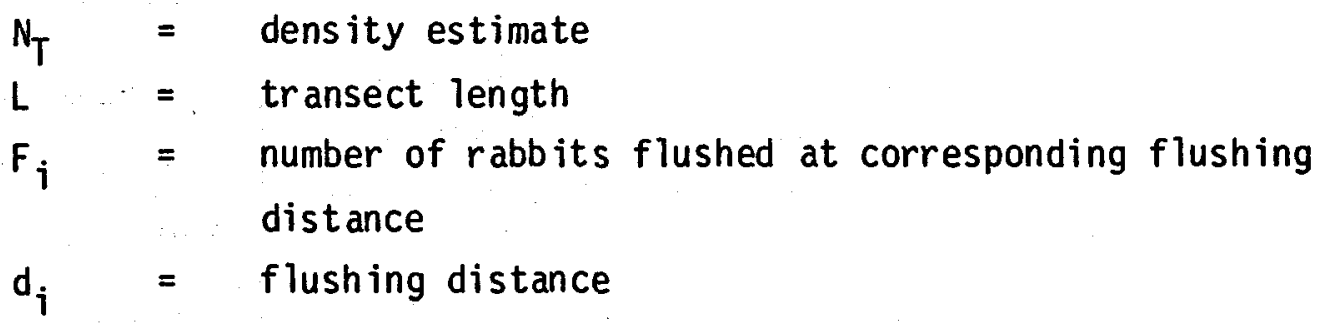

The correction factor of Gross et al ${ }^{17}$ (multiplying $N_{T}$ by 1.14) was used to reduce the underestimate of the Hayne method. By applying the census criteria of Gross et al, the Raft River Valley data was consistent with the long-term population data they collected for the adjacent southern Idaho-northern Utah area. The two jackrabbit populations could then be compared.

Pygmy Rabbit Census. The pygmy rabbit, a species which appears to have an obligatory-like relationship with sagebrush, 18 is endemic to the Great Basin where it occurs in scattered colonies. Because of its restricted distribution and undetermined population status, this species receives special attention from state and federal land management agencies. In the course of the jackrabbit census, two pygmy rabbit colonies were found in the valley, one within the geothermal area. Aside from these two colonies, no pygmy rabbits were sighted. In 1980, research was initiated to determine population density and to characterize the 


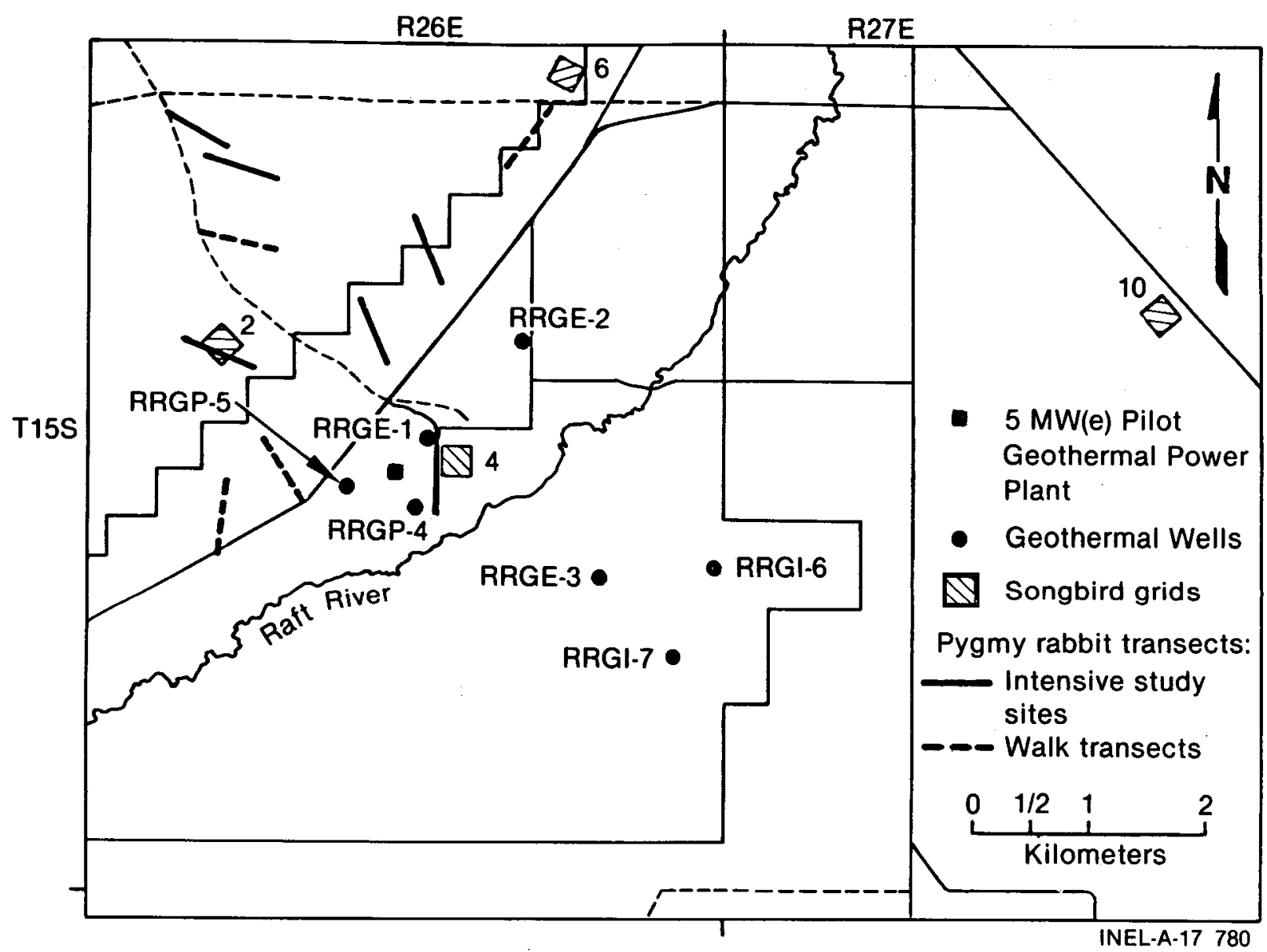

Figure 10. Location of rabbit transects and songbird grids. 
habitat parameters of the colonies. Because it is difficult to census this secretive small mammal, three different sampling methods were employed. To locate the transects within the colony, intensive sampling sites were chosen on the basis of previous observations.

Walk transects, ${ }^{16}$ fecal pellet counts, ${ }^{18}$ and capture/recapture ${ }^{19}$ were the three census methods used. Population density estimates obtained by these methods were transformed ${ }^{20}$ for parametric statistical analysis. Vegetation analysis of pygmy rabbit habitats was conducted using the point-quarter method 21 to quantify density, height, and cover of woody vegetation. Herbaceous cover, litter, bare soil, and rock cover were evaluated using the basic technique recommended by Daubenmire. 22 Importance indices for shrub species were calculated using the combined values for relative frequency, relative cover and relative density. ${ }^{23}$

\section{Results and Discussion}

Jackrabbit Population. The density of the black-tailed jackrabbit population, 17,24 was estimated to be $309 / \mathrm{km}^{2}$ in $1978,287 / \mathrm{km}^{2}$ in 1979, and $188 / \mathrm{km}^{2}$ in 1980 . The black-tailed jackrabbit population densities for 1978 and 1979 are high when compared with population estimates in the literature, $17,25,26$ indicating that the population was at or near peak-population density in 1978. A qualitative indication of the population was also obtained by counting jackrabbits killed on an 8-km stretch of the only paved road through the valley. In 1978, 85 dead jackrabbits were counted. In 1980, at the same time of year and over the same stretch of road, only 32 dead jackrabbits were counted. These observations support the walk transect data, indicating a substantial population decline over the 2-year period.

The decline in the jackrabbit population from 1979 to 1980 , despite a mild winter for that year, appears in part to be the result of an epizootic outbreak in the population in late 1979. In late summer of 1979, abnormal jackrabbit behavior was observed, evidenced by "dazed" individuals seemingly unaware of the surrounding environment. Jackrabbits were 
frequently found dead in the field from no apparent external cause. Autopsies revealed tularemia as the probable cause of death. Very few young jackrabbits were present in the 1980 summer population, composing only $19 \%$ of the total.

Similar transects were run in Curlew Valley (located about $35 \mathrm{~km}$ east of Raft River Valley) during 1978 and 1979, yielding population density estimates of $50 / \mathrm{km}^{2}$ and $66 / \mathrm{km}^{2}$, respectively. The much lower jackrabbit densities in Curlew Valley are probably a reflection of the more intense agricultural and rangeland development than that found in Raft River Valley. The altered environment appears to hold the jackrabbit population in check, so it does not fluctuate as much as populations in large native stands of vegetation. A cyclic pattern is evident in population data collected in Curlew Valley by Gross et al, 17 indicating that the last population peak occurred about 1970.

Pygmy Rabbit Population. The mortality factors contributing to the decline of the black-tailed jackrabbit population were diseases, external and internal parasites, predation, and poor nutrient intake resulting from intense grazing pressure exerted by the high population density. These factors may also affect other sympatric species of lagomorphs. In 1980 the pygmy rabbit population showed a noticeable decline from the spring through the summer. Overall, pygmy rabbits on the six study sites averaged 3.6 individuals/ha and $r$ anged from 0.8 to 8.4 individuals/ha. The location of the colonies appeared to be related to very specific habitat conditions. Big sagebrush (Artemisia tridentata) was by far the most dominant woody vegetation observed in conjunction with pygmy rabbits. The average importance index of big sagebrush along the six 500-m walk transects was located with in the areas intensively used by pygmy rabbits $59.5 \%(c v=39.2 \%)$. The same trend was evident for the average importance indices of grasses and grass-like species. Along the six 500-m walk transects, this vegetation had an average importance index of $12.8 \%$ $(\mathrm{cv}=82.4 \%)$, and increased to $21.5 \%(\mathrm{cv}=53.3 \%)$ at trap sites within the five intensive use areas. Grasses have been identifjed as important components for pygmy rabbit diets in spring and summer, 18,27 
A multiple regression analysis of the average importance indices of big sagebrush and grasses and grass-like plants at the five trap sites accounted for $91.1 \%$ of the observed variability in population density of pygmy rabbits on the same sites. A similar test with importance indices of big sagebrush and grasses and grass-like plants along the six 500-m walk transects showed these measurements accounted for $68.9 \%$ of the variability observed in estimates of population density of pygmy rabbits. Height of woody vegetation was not taken into account in the importance indices for woody vegetation. Used alone, height of big sagebrush at trap sites and along walk transects accounted for $39.2 \%$ and $59.2 \%$, respectively, of the observed variability in estimates of pygmy rabbit density.

The results of this research have more clearly delineated the close association between big sagebrush and pygmy rabbits. Pygmy rabbits select habitats where stands of big sagebrush fit within high and low limits of height, cover, density and frequency.

\section{Raptors}

\section{Introduction}

The ferruginous hawk (Buteo regalis) population of the Raft River Valley exhibits one of the highest densities and productivities known for this species. The decline of the general population throughout its range has prompted state and federal wildife protection agencies and environmental organizations to express concern for their welfare. The population decline has been attributed to an intolerance to human activity. When the parent hawks are sensitized during incubation, they do not properly care for the young, resulting in mortality due to exposure, starvation, and predation. The primary objective of the Raft River perturbation research has been to determine the levels of disturbance that can be tolerated by the sensitive ferruginous hawks without adversely affecting their nesting success. 
Methods

In 1978 and 1979, the hawks were subjected to various disturbances similar to activities associated with geothermal development. The success and productivity of treatment nests were compared with control nests. 15 The flushing distance was recorded; however, a concurrent study suggested that the stress level of a captive ferruginous hawk rises long before the bird flushes. 28 The 1980 radiotelemetry study in the Raft River Valley monitored increased heart rates as an attempt to more accurately determine the distance at which these birds actually become stressed.

Several unique problems were encountered because this species does not tolerate human activity near the nest site during incubation. The standard procedure of attaching the transmitter directly to the bird would have caused desertion, resulting in both nest failure and loss of the transmitter. To avoid this, a transmitter sensitive enough to detect the heart rate of an incubating bird was encased in an addled ferruginous hawk egg and placed in the nest along with the other eggs. This method had not been previously tried; however, interest by the scientific community was expressed in testing and perfecting this approach. By using radiotelemetry to determine an increase in heart rate, a more accurate assessment of stress was determined and correlated with the flushing data from the previous two years.

\section{Results and Discussion}

Several problems developed during the research, as should be expected when a new approach is tested. However, some very useful data were obtained. Transmitter sensitivity and orientation needed to be adjusted throughout the early phase of the study. Additionally, the inclement weather of May and the sharp decline in the jackrabbit population left the birds in poor physiological condition, thus decreasing their tolerance level and increasing the probability of nest failure. 
The first two attempts at placing a transmitter in ferruginous hawk nests resulted in nest desertion. The reason for these nest failures may have been a result of the generally poor physiological condition of the hawks or the different methods used in 1980. In previous years of this study, the incubating hawks were not approached closely and the trees were not climbed. After these two failures, the transmitter was successfully placed in a Swainson's Hawk (Buteo swainsoni) nest, a species that is more common throughout the West, but has similar sensitivity levels.

After solving the transmitter difficulties, another attempt was made to plant a transmitter in a ferruginous hawk nest. A basal heart rate of approximately 130 beats per minute and an increased heart rate as researchers approached the nest were noted. Unfortunately, this pair also deserted and the transmitter was again placed in a Swainson's hawk nest. Heart rates of the Swainson's hawks typically increased by $50 \%$ when a human or vehicle within $300 \mathrm{~m}$ was first sighted by the incubating bird. The heart rate continued to increase until it was double the basal rate.

These data confirm the results obtained from a captive ferruginous hawk. ${ }^{28}$ Stress, as measured by a rise in heart rate, begins to occur long before the hawk leaves the nest, at a distance of up to nine times farther than that at which the bird actually flushes. This information will be used in determining a "buffer zone" that should be maintained around active nest sites during the breeding season. The 1980 data inadvertently confirmed the extreme sensitivity of the ferruginous hawk during the nesting season, as illustrated by the desertion of three territories after only brief visits to the nest site.

Manuscripts resulting from this research include discussions of the breeding ecology of the long-eared owl (Asio otus), the nesting interrelationship between the ferruginous hawk and Swainson's hawk, a summary of the raptor ecology of Raft River Valley, Idaho, 29 and a detailed summary of the raptor perturbation and radiotelemetry research. 
Songbirds

\section{Introduction}

The songbird study, initiated in 1977, provides baseline data on passerines in the Raft River Valley. The sage thrasher, (Oreoscoptes montanus), sage sparrow (Amphispiza belli), and Brewer's sparrow (Spizella brewer $i)$ are common in the sagebrush plant associations surrounding the geothermal site. Although Brewer's sparrows can adapt to rangeland habitats, sage sparrows and sage thrashers are semi-obligates of sagebrush, greasewood or shadscale communities. Due to their restricted habitat requirements, variations in the population of these two species may be used as indicators of changes in habitat resulting from geothermal development.

\section{Methods}

In 1977, four 16-ha study plots were established. 30 These plots represent the major habitat types found in the immediate area of the geothermal site (Figure 10). Censuses were conducted during 1977, 1978 and 1980 once every 12 days in May, June and early July. The researchers used the census techniques of Williamsen et al ${ }^{31}$ and White et al ${ }^{32}$ and recorded the total number and species of birds observed and the territory size.

Results and Discussion

The nesting success and distribution of breeding birds during the 1980 study were primarily influenced by changes in vegetation composition resulting from abnormal climatic conditions. Data collected in 1980 varied from that obtained in 1977 and 1978 as a result of unusually heavy rains in May and June. Total precipitation for May and June was $121 \mathrm{~mm}$ in 1977 and $55 \mathrm{~mm}$ in 1978. Total precipitation for 1980 was $158 \mathrm{~mm}$, or $31 \%$ greater than the 1977 level and $185 \%$ greater than the 1978 level. 
The increase in precipitation created differences in the vegetation on the sample plots from previous years (Table 8). Specifically, grass cover for all plots was $185 \%$ of 1977 levels. The greatest variation in vegetation occurred on plot 4 which is in a disturbed area near RRGE- 1 . In 1977, this plot had a grass cover of $2.85 \%$ compared with $21.1 \%$ in 1980 . The other plots did not show the same marked increase in ground cover because these plots were located on drier hillsides with more rapid drainage than plot 4.

The effect of this increase in vegetation cover is apparent in the Brewer's sparrow data from plot 4. In 1977, 34 Brewer's sparrows were observed compared to 5.6 in 1978. In 1980, no Brewer's sparrows were observed in plot 4 during the extremely wet period from May to mid-June when grass cover was dense. In late June, it was considerably drier and six Brewer's sparrows established nests in plot 4. In July, 16 Brewer's sparrows were observed in this plot. The average population of Brewer's sparrows over the three month period was eight.

The increase in grass cover on plot 4 attracted four pairs of Vesper Sparrows in May and June of 1980 (Table 9). These birds nest in grass cups in open fields and meadows. They were observed in plot 4 only in 1980 when the grass cover increased greatly over the other years of the study.

The variation in songbird densities at the other plots was not as dramatic as in plot 4 (Table 10). The vegetation on these better drained hillsides was not as strongly influenced by the increased precipitation. The predominant species of these sites are sage thrashers and sage sparrows which select large shrubs, such as big sagebrush, for nests. The shrub cover was not noticeably affected by the increase in precipitation; therefore, little change was observed in the population of these birds.

Greater precipitation and the resulting changes in vegetation composition may have affected the territory size of breeding birds. For example, in 1977 the average territory size of Brewer's Sparrows was 
taOLE 8. PERCENT RELATIVE TREQUENCIES OF PLANT OVERSTORY AND PERCENT COVER OF UNDERSTORY AT THE. SOMGBiRD SITES

\begin{tabular}{|c|c|c|c|c|c|c|c|c|c|c|c|c|c|c|c|c|c|c|}
\hline & \multicolumn{18}{|c|}{ Study sttes } \\
\hline & \multicolumn{3}{|c|}{2} & \multicolumn{3}{|c|}{4} & \multicolumn{6}{|c|}{6} & \multicolumn{6}{|c|}{10} \\
\hline & \multirow[b]{2}{*}{1977} & \multirow[b]{2}{*}{1978} & \multirow[b]{2}{*}{1980} & \multirow[b]{2}{*}{$\underline{1977}$} & \multirow[b]{2}{*}{$\underline{1978}$} & \multirow[b]{2}{*}{1980} & \multicolumn{3}{|c|}{ Brush Area } & \multicolumn{3}{|c|}{ Grass Area } & \multicolumn{3}{|c|}{ Brush Aren } & \multicolumn{2}{|c|}{ Grass Area } & \multirow[b]{2}{*}{1980} \\
\hline & & & & & & & 1977 & 1978 & 1980 & 1977 & 1978 & 1980 & 1977 & $\underline{1978}$ & 1980 & $\underline{1977}$ & 1978 & \\
\hline \multicolumn{19}{|l|}{ OVERSTORY } \\
\hline Sagelrush & io & 65 & 71 & 14 & 21 & 11 & 100 & 100 & 100 & 0 & 0 & 0 & -- & -- & -- & 0 & 0 & 0 \\
\hline Greasewood & 40 & 35 & 22 & 82 & 79 & 89 & 0 & 0 & 0 & 0 & 0 & 0 & -. & -- & 97 & 0 & 0 & 0 \\
\hline Pabbit Lrust & 0 & 0 & 0 & 5 & 0 & 1 & 0 & 0 & 0 & 0 & 0 & 0 & $\cdots$ & $\cdots$ & 0 & 0 & 0 & 0 \\
\hline Shadscale & 0 & 0 & 0 & 0 & 0 & 0 & 0 & 0 & 0 & 0 & 0 & 0 & --- & -- & 3 & 0 & 0 & 0 \\
\hline \multicolumn{19}{|l|}{ UNDERSTORY } \\
\hline Grasses & 7.7 & 5.2 & 19.5 & 3.0 & 2.8 & 18.5 & $\cdots$ & $\cdots$ & 21.4 & 24.7 & 24.5 & 16.0 & $\ldots$ & -.. & 16.9 & 19.6 & $\cdots$ & 7. \\
\hline Forbs & 1.2 & 0.7 & 2.9 & 4.5 & 6.7 & 7.4 & $\cdots$ & -.- & 13.9 & 28.5 & 15.6 & 21.5 & $\cdots$ & -.- & 12.5 & $\cdots$ & $\cdots$ & 14.1 \\
\hline lactus & -- & 0.5 & 0.4 & $\cdots$ & -- & 5.7 & -- & $\cdots$ & 2.8 & 1.8 & 0.8 & 0.4 & $\cdots$ & $-\cdot$ & 2.8 & 0.2 & $.0-$ & 2.7 \\
\hline Bareground & 64 & 51 & 65 & 78 & 70 & 55 & 58 & 63 & 49 & 42 & 57 & 48 & :-- & $\cdots$ & 58 & 36 & 38 & 63 \\
\hline $\begin{array}{l}\text { Total Living } \\
\text { Cover }\end{array}$ & 36 & 49 & 35 & 20 & 30 & 45 & 45 & 37 & 51 & 60 & 43 & 52 & $\cdots$ & $\cdots$ & 42. & 67 & 62 & 37 \\
\hline
\end{tabular}


TABLE 9. SONGBIRD SPECIES ENCOUNTERED ON STUDY SITES AND THEIR FREQUENCY

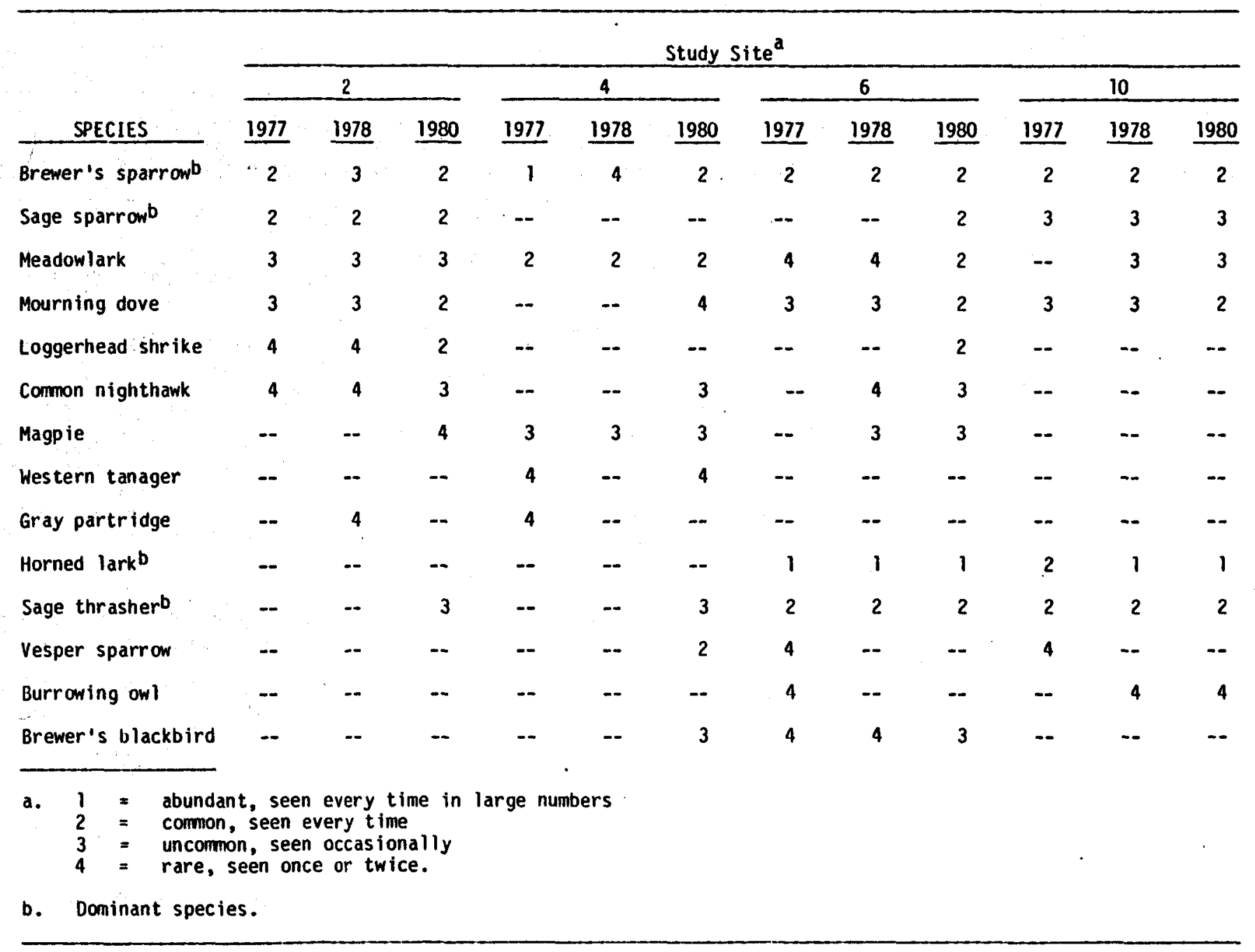


TABLE 10. DENSITY OF MAJOR BREEDING SONGBIRDS ON 16-ha PLOTS

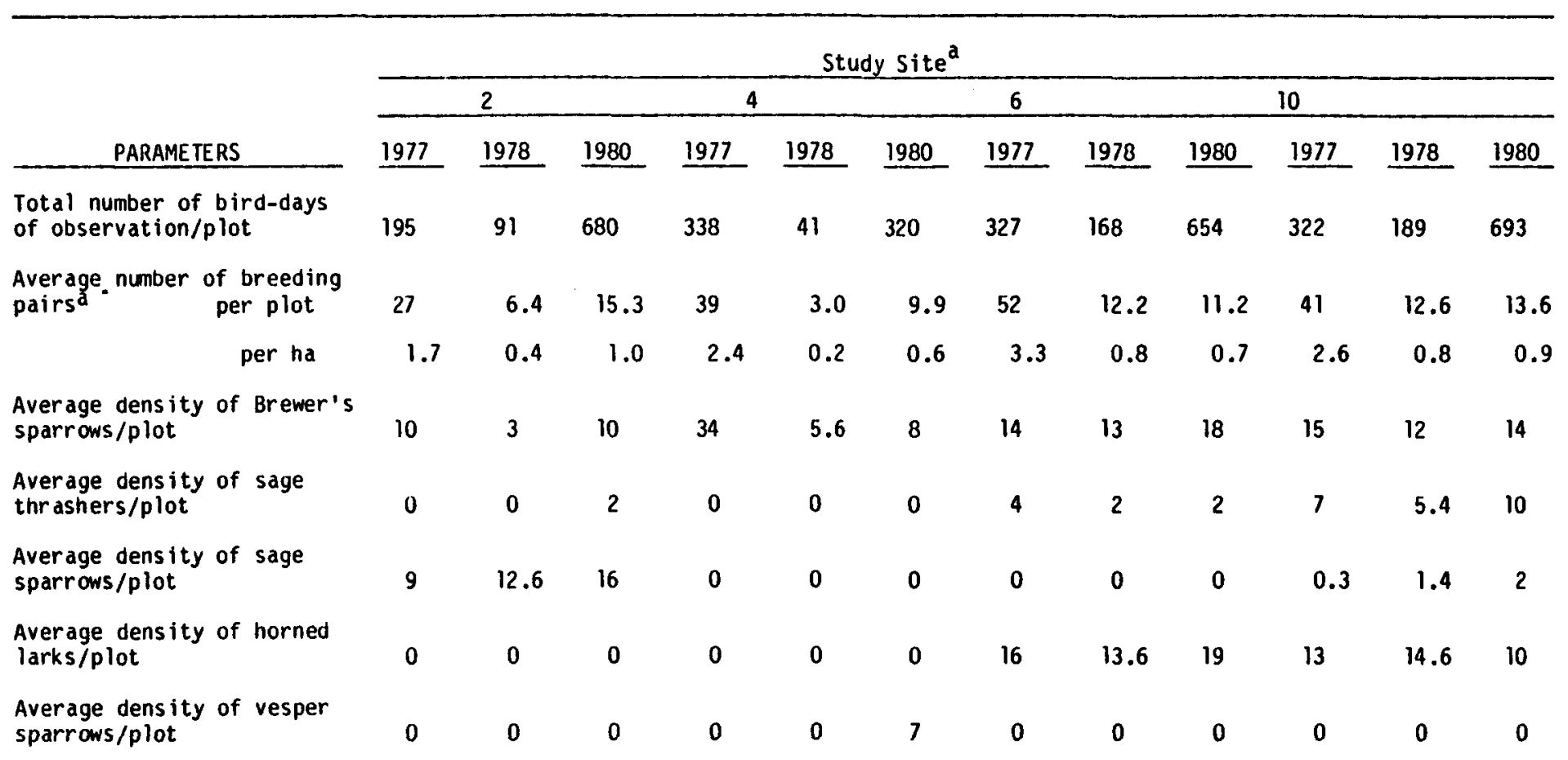

a. 1977 data include Brewer's sparrows, sage thrashers, and sage sparrows,

1978 data include only sage sparrows and Brewer's sparrows.

1980 data include all of the above and also meadowlarks, mourning doves, loggerhead shrikes, and Vesper sparrows. 
0.34 ha compared to 0.65 ha in 1978. In 1980 the territory size dropped to $0.22 \mathrm{ha}$, perhaps reflecting the increase in insects resulting from the denser ground cover.

In 1980, data on the territory size and distribution of species not recorded in previous years were collected. Territory size estimates were established for sage thrashers ( $1.23 \mathrm{ha}$ ), Vesper Sparrows (1.59 ha), loggerhead shrikes (2.10 ha) and meadowlarks (2.56 ha).

\section{Conclusions}

This research shows that songbirds are influenced by changes in climatic conditions, habitat type and food base. Passerine species that are very habitat-specific are very sensitive to slight changes in that habitat, and would act as indicators of environmental change. Species that are more adaptable to changing environmental conditions will not be good indicator organisms. For sagebrush, greasewood, or shadscale communities, sage sparrows and sage thrashers may be sensitive indicators while the ubiquitous Brewer's sparrows would not be, due to their general use of habitat and adaptability. The best indicators of environmental changes will probably be absolute density changes of breeding birds, particularly changes in distribution or numbers of sage sparrows and sage thrashers. 
Developing the geothermal resources of the Raft River Valley may affect the people in the local communities. This development offers residents many benefits and opportunities, but may also result in undesirable changes. The human environment monitoring program was designed to identify the potential changes that might result from geothermal development. These data will be used to minimize long-term adverse impacts and maximize beneficial changes.

\section{Socioeconomics}

\section{Introduction}

Geothermal development in the Raft River Valley is not likely to result in a "boom town" or other radical changes. However, it is important to predict the socioeconomic changes and to analyze the potential problems associated with geothermal development. The Raft River socioeconomic study conducted in $1979^{33}$ inventoried the existing socioeconomic characteristics and historic changes. In addition, future population trends and economic activities were projected assuming no significant developments would occur. The second phase of this study was completed in $1980 . .^{34}$ The objectives were to identify development scenarios and to predict the effects each may have on employment, the population, land use, and the public sector.

\section{Development Scenarios}

The three scenarios for geothermal development in the Raft River valley used in this study are described below.

Case 1. 5-MW(e) power plant, 10-acre greenhouse by 1982, and a $100,000-1 b / y r$ aquaculture production facility by 1981 . 
Case 2. Two 5-MW(e) plants, 20-acre greenhouse by 1983, and $200,000-1 \mathrm{~b} / \mathrm{yr}$ aquaculture production by 1981 .

Case 3. 30- to 50-MW(e) plant by 1985, 30-acre greenhouse by 1983, and $500,000-\mathrm{lb} / \mathrm{yr}$ aquaculture production by 1982 .

Although Case $l$ is the only possible development alternative for the Raft River Valley, this was not apparent until after the study had been initiated. The data for Cases 2 and 3 are included since they may have some application to geothermal development in other areas.

Results and Discussion

Employment. Geothermal development in the Raft River area will generate more jobs, boost the economy and increase the average standard of living. By 1986, employment in the county could increase by 3 to $9 \%$, depending on the extent of development.

The local labor pool is insufficient to supply some of the skilled positions associated with geothermal development. Under Cases 1 and 2, non-locals will have to be recruited for $50 \%$ of the power plant jobs, $20 \%$ of the fish farm and greenhouse jobs and $25 \%$ of all other directly- and indirectly-related $\bullet j o b s$. Case 3 would require a higher proportion of non-locals because the local labor supply is limited. Employment multipliers were used to calculate the number of indirectly-related jobs that would be created for each non-local recruited. The employment multiplier used for construction workers is 0.2 , and 0.8 is used for operations employees. In other words, for every 10 new construction workers, two people will be needed in support positions.

The number of new positions that will be created and the percentage that will be filled by non-locals can then be calculated. For Case 1, 149 new employees will be required by 1983. This figure includes construction as well as all indirectly-related positions. Of these, 
58 employees (39\%) will be from outside of the area. For Case 2, 288 new employees will be hired of which 112 will be non-locals. These figures increase to $199(47 \%)$ non-locals and 419 permanent positions for Case 3 .

Population. A population employment multiplier of 2.51 is used to estimate the number of family members that will move into the area with each new non-local worker. The total increase in population expected in the area by 1986 is 146 for Case 1, 281 for Case 2, and 499 for Case 3. The "Relative Attractive Force" of each town in the area is then calculated; $42.2 \%$ of the new residents can be expected to live in Burley, $35.1 \%$ in Malta, $11.4 \%$ in 0ak ley, $5.4 \%$ in Alma, $3.2 \%$ in Albion, and $2.7 \%$ in Declo. To calculate the housing demand, it is assumed that $50 \%$ will live in single-family houses, $20 \%$ in multiple-family dwellings, and $30 \%$ in mobile homes.

Land Use. No significant impacts on land use are predicted for any of the cases. There are two reasons for this:

1. The amount of land required for development is small relative to the total available land in the county, and

2. The number of people that would move into the area is small relative to the existing population base.

More specifically, Case 1 will require 13.8 to 17.0 acres. Even for Case 2, by 1983 the amount of impacted land would be 59 to 73 acres, or the equivalent of 6 to 7 city blocks.

Public Sector. Public sector impacts will be dispersed throughout the county and no significant problems are expected. Assessed valuation will increase by $1.0,1.9$ and $5.4 \%$ for Cases 1,2 , and 3 respectively. Sales tax revenues could amount to 1.3 to $3.7 \%$ of the 1979 base and would decrease state tax rates and benefit public services. Additional revenue would be collected from state income tax (4 to 11\%), corporate net income 
$\operatorname{tax}(4.3$ to $16 \%)$, and property tax. When combined, these increases in revenue are not insignificant, and will be important to local and state governments.

Geothermal development will have an impact on public schools in the area by increasing enrollment. The secondary school in Malta can absorb the additional students under any development case. Burley public schools and the Malta elementary school, however, will exceed their nominal capacity even without geothermal development. Under development Case 3 , an additional 1 or 2 classrooms and teachers are needed. Planning for expansion should precede development by a few years. Increases in. enrollment $c$ an have a positive impact, as it raises the tax base of the community and might enhance the quality of education.

In summary, three scenarios for geothermal development are outlined, and a summary of predicted impacts for Case 1 are presented in Table 11. All alternatives are expected to generate more jobs, boost the economy, and increase the standard of living. All anticipated problems could be mitigated through proper planning. Most predicted effects are viewed as positive, and the area should not change radically, even under the development out lined in Case 3. 
TABLE 11. SUMMARY OF EMPLOYMENT, LABOR SOURCE, AND POPULATION IMPACTS, 1980-1986 UEVELOPMENT ALTERNATIVE: CaSe 1

\begin{tabular}{|c|c|c|c|c|c|c|c|c|c|c|c|c|c|c|c|}
\hline \multirow{2}{*}{$\begin{array}{l}\text { Year } \\
\text { Quarter }\end{array}$} & \multicolumn{2}{|c|}{1980} & \multicolumn{4}{|c|}{1981} & \multicolumn{4}{|c|}{1982} & \multicolumn{4}{|c|}{1983} & \multirow{2}{*}{$\begin{array}{c}\frac{1984-1986}{\text { AlT }} \\
\text { Quarters } \\
\end{array}$} \\
\hline & 3 & 4 & 1 & 2 & 3 & 4 & 1 & 2 & 3 & 4 & 1 & 2 & 3 & 4 & \\
\hline Total New Jobs: & 27 & 37 & 52 & 84 & 84 & 90 & 85 & 115 & 129 & 130 & 142 & 149 & 149 & 149 & 149 \\
\hline Direct & 24 & 35 & 35 & 56 & 56 & 58 & 53 & 78 & 93 & 83 & 83 & 83 & 83 & 83 & 83 \\
\hline Indirect & 3 & 2 & 17 & 28 & 28 & 32 & 32 & 37 & 36 & . 47 & 59 & 60 & 66 & 66 & 66 \\
\hline \multicolumn{16}{|l|}{ Source of Labor: } \\
\hline Local residents & 13 & 15 & 26 & 53 & 53 & 55 & 51 & 74 & 82 & 77 & 86 & 91 & 91 & 91 & 91 \\
\hline Outside region & 14 & 22 & 26 & 31 & 31 & 35 & 34 & 41 & 47 & 53 & 56 & 58 & 58 & 58 & 58 \\
\hline Total Population Impacta & 35 & 55 & 65 & 78 & 78 & 88 & 85 & 103 & 118 & 133 & 141 & 146 & 146 & 146 & 146 \\
\hline $\begin{array}{l}\text { Household units--single } \\
\text { workers }\end{array}$ & 2 & 3 & 4 & 5 & 5 & 5 & 5 & 6 & 7 & 8 & 8 & 9 & 9 & 9 & 9 \\
\hline $\begin{array}{l}\text { Household units--married } \\
\text { workers }\end{array}$ & 9 & 14 & 17 & 20 & 20 & 22 & 22 & 26 & 30 & 34 & 36 & 37 & 37 & 37 & 37 \\
\hline Total--household units & 11 & 17 & 21 & 25 & 25 & 27 & 27 & 32 & 37 & 42 & 44 & 46 & 46 & 46 & 46 \\
\hline School-age children & 11 & 18 & 21 & 25 & 25 & 28 & 27 & 33 & 37 & 42 & 45 & 46 & 48 & 48 & 48 \\
\hline
\end{tabular}

a. Assumptions: (1) Average family size for married workers is 3.7 persons.

(2) In one third of families moving into the region, both husband and will will be employed.

(3) 15 percent of new workers will be single.

(4) 74 percent of children will be of school age. 


\section{Fluoros is}

\section{Introduction}

High concentrations of fluoride in water supplies is a potential health hazard to humans and other animals. Low levels of fluoride in water may strengthen teeth, but excessively high levels may lead to a dental disease known as fluorosis. Symptoms of fluorosis include mottled or discolored teeth, rapid wear, and erosion of enamel from dentine. Humans are susceptible to fluorosis until age 16; the most critical years are from ages 2 to 10 .

High fluoride concentrations are common in geothermal fluids. Concentrations found in Idaho are as high as $30 \mathrm{mg} / 1$. In Raft River, the geothermal fluids contain between 5 and $10 \mathrm{mg} / 1$ fluoride, and high concentrations $(6 \mathrm{mg} / \mathrm{l})$ are found in some irrigation and domestic wells. An anomalously high concentration of fluoride $(14 \mathrm{mg} / 1)$ was found in a spring but the water is not consumed by either livestock or humans.

The Raft River Fluorosis Study, initiated in 1978, has concentrated on monitoring dental health in school children and fluoride levels in domestic wel1s. 35 Out of 270 children examined by a dentist in 1978, 132 had some type of dental anomaly. Of these, 52 had lesions that are typical of fluorosis. These figures represent a level of dental health which is unusually poor.

If incidences of fluorosis in the Raft River Valley were induced by the water supply, a direct.relationship between fluorosis and fluoride content of water would be expected. Statistical analysis of the Raft River data indicates that at the $99.5 \%$ confidence interval, the fluoride content of the domestic water is not related to the incidences of fluorosis in children. The 1980 fluorosis study was designed to determine how the children are obtaining fluoride in the Raft River Valley since they are not obtaining it from domestic water. Several possibilities exist to account for the unexplained dental fluorosis. 
1. Raft River Valley residents may be obtaining fluoride from home-grown vegetables. Although plant roots generally discriminate against fluoride uptake, the plant leaves may accummulate fluoride from the air or from sprinkler irrigation.

2. Fluoride may be obtained from milk. Cows can ingest fluoride by grazing on plants irrigated with high fluoride water or by drinking from wells with a high fluoride concentration.

3. Children may be obtaining fluoride during the summer while moving irrigation pipes. Fluoride may enter the body through inhalation of moist air. Water used for irrigating may have much higher fluoride levels than the acceptable federal drinking water standard for the Raft River region of $2 \mathrm{mg} / 1$.

4. There may be a correlation between incidence of fluoros is and the number of years of residence in the Raft River Valley.

5. Symptoms of fluorosis may be typical of other dental diseases. Poor dental health care may result in higher incidences of dental anomalies. The age when a child first began dental visits may aiso be significant.

Methods

A questionnaire designed to address these possibilities was distributed in the Almo and Raft River elementary schools and Raft River High School. These questionnaires were compared to the dental classification from the 1978 study and analyzed statistically to determine if any correlations existed. A description of the dental classification used in 1978 by the examining dentist follows.

0 Normal. Smooth, translucent, glossy white appearance of ename 1; tooth is of normal shape and size. 
1 Questionable effect. Some deviation from normal, exact cause may or may not be determinable; cause may be metabolic (nutritional, some diseases, high fever, prolonged use of some antibiotics, or others); may have enamel flecks but not typical mottling.

2 Slight fluoride effect. Slight mottling of ename1; best observed as horizontal striations with transmitted light; may have slight staining; no increase in normal rate of wear.

3 Moderate fluoride effect. Definite mottling; large areas of opaque chalky white enamel or generalized mottling of entire tooth; tooth may have a slightly increased rate of wear and may be stained.

4 Marked fluoride effect. Definite mottling, hypoplasia, and hypocalcification; may have pitting of enamel; with use, tooth will have increased rate of wear and may be stained or discolored.

5 Severe fluoride effect. Defin ite mottling, hypoplasia, and hypocalcification; with use tooth will have excessive increase in rate of wear and may have erosion or pitting of enamel. Tooth may be stained or discolored.

Duplicate water samples were collected in May and again in August 1980 from the 46 domestic wells previously sampled in 1978; the results were compared with those from the previous tests. Samples were also taken from the Malta high school and some irrigation and cattle wells.

Results and Discussion

The fluoride content of the domestic water samples was low and would not be expected to cause fluorosis. Forty-four out of 46 domestic wells in the Raft River Valley sampled in 1978 had less than the federal drinking water standard for the region of $2 \mathrm{mg} / 1$ fluoride. The average fluoride 
concentration in these 44 wells was $0.50 \mathrm{mg} / 1$ (standard deviation = $0.30 \mathrm{mg} / 1$ ) in 1978. This is less than the $1 \mathrm{mg} / 1$ recommended by the American Dental Association (ADA) and the American Medical Association (AMA). Only 2 wells had high fluoride concentrations $(6 \mathrm{mg} / 1)$ but one family had no children and the other family did not drink this water. The fluoride concentrations in domestic water samples collected in 1980 were comparable to the 1978 levels. The average concentration was $0.68 \mathrm{mg} / 1$ in May (standard deviation $=0.38 \mathrm{mg} / 1$ ) and $0.64 \mathrm{mg} / 1$ in August (standard deviation $=0.37 \mathrm{mg} / 1$. However, the 1980 estimated averages appear higher than actual because $63 \%$ of the wells had less than the $0.5 \mathrm{mg} / 1$ detection limit, but 0.5 was used in computing the averages. Water from the Raft River High School contained less than $0.5 \mathrm{mg} / 1$ fluoride. These results do not indicate that there is enough fluoride in the drinking water to induce the high incidence of dental anomalies.

Nine irrigation wells throughout the valley were also sampled, and they averaged $1.22 \mathrm{mg} / 1$ fluoride. Two of these wells were higher $(4.32$ and $2.10 \mathrm{mg} / 1)$ than the federal drinking water standard, and three were lower than the lower detection 1 imit of $0.5 \mathrm{mg} / 1$. Although some of the irrigation water used in the valley may be high enough to induce dental fluorosis there does not appear to be any direct relationship between dental classification and either existence of home vegetable gardens or the summertime occupation of the students. Eighty-five percent of the students have a garden at home, and $68 \%$ move irrigation pipes in the summer. Based on statistical analysis both of these hypotheses can be rejected at the $90 \%$ confidence interval.

Studies conducted on animals with high fluoride intakes show that very little fluoride is excreted through the mammary glands. ${ }^{36}$ This would lead to the conclusion that the children are not receiving fluoride from the milk they drink, even if the water supplies used by the cattle are high in fluoride. Only seven children lived on dairy farms; six of those had dental classifications of 0 or 1 , and only one child had a classification of 2. The milk produced in Raft River Valley that is processed does not return to the valley but is distributed to other areas. 
Incidences of dental fluorosis did not appear to correlate with the number of years a child had lived in the Raft River Valley, or the percentage of time spent in the valley during the critical years from 2 to 10. However $71 \%$ of the children with dental classifications of 3 or 4 and $25 \%$ of those with classifications of 2 had lived somewhere besides the Raft River Valley. One family had recently moved from Nevada; two children had class 3 teeth and the other had class 4 . It is possible that the children who had lived elsewhere may have been exposed to high levels of fluoride in those other places. However, this does not explain the exposure of the children that have always lived in the Raft River Valley and also exhibit symptoms of fluorosis (up to classification 3 ).

No relationship was found between the age when dental visits were initiated and dental classification, or between present age and dental classification. The only correlation found that is statistically significant is between dental classification and frequency of visits to the dentist. Since a dental classification of 1 is a questionable fluoride effect, this was not used in the correlation. Frequency of dental exams of the students with fluorosis symptoms (classes 2, 3 and 4 ) averaged once every 1.42 years compared with 1.19 years for those showing no fluoride effect (classification 0 ). This is statistically significant using the t-test at the $95 \%$ confidence interval. Students that had dental exams every 6 months had an average dental classification of 0.64 . These scores increased with decreasing frequency of dental visits, with those students visiting the dentist once every 2 years having the highest average dental classification $(\bar{X}=1.33)$.

If the dental anomalies exhibited by the Raft River Valley children are truly symptoms of fluorosis, then the direct correlation observed between dental class and infrequency of dental visits is puzzling. One would not expect incidences of fluorosis to be correlated with poor dental care. These results could lead one to conclude that the symptoms were improperly diagnosed and are not related to fluorosis; at least not in all cases. However, Dr. Hurst, the examining dentist, felt very confident that 
symptoms of fluorosis are unique and not easily mistaken. ${ }^{37}$ Those students with questionable fluorosis symptoms were given a dental classification of 1 .

\section{Conclusion}

If one assumes that the symptoms observed were properly diagnosed, then the incidences of dental fluorosis in the Raft River valley are abnormally high. The cause remains a paradox due to the low fluoride levels in the domestic water. It was not possible to pinpoint any other source of fluoride in the valley from the 1980 study. The children are not receiving detrimental amounts of fluoride from the drinking water supplies, nome-grown vegetables, home-produced milk, or irrigation water, and incidences of fluorosis are not correlated with residence time in the valley. Fluoride could be obtained from several different sources not associated with the Raft River Valley. Many of the children displaying moderate to marked fluoride effects have lived elsewhere and may have been exposed to high fluoride levels at their previous residences. Symptoms diagnosed as fluorosis during the 1978 examination may have been symptoms created by trauma, prolonged use of antibiotics, high fevers, poor nutrition, or other diseases during the formative years. 


\section{REFERENCES}

1. S. G. Spencer and D. M. Callan, An Analysis of the Response of the Raft River Monitor Wells to the T979 Injection Tests, EGG-2057, September 1980.

2. P. Skiba, and L. Hull, An Analys is of the Response of the Raft River Monitor Wells to the 1980 Injection Tests, (in press), EGG-GTH-5394, T981.

3. J. L. Coffman and C. A. Von Heke, Earthquake History of the United States, U.S. Department of Commerce, NOAA Environmental Data Service, Pub. 41-1, 1973.

4. D. B. Slemmons, A. E. Jones, J. I. Gimlett, "Catalogue of Nevada Earthquakes, 1952-1960," Bull. Seismol. Soc. of Amer., 55, 2, 1965.

5. A. H. Dahl and B. D. Johnson, "Preliminary Results of a Microseism Study for the Region Around the Snake River Plain (1973-March 1974)," Idaho Academy of Science, Ricks College, Rexburg, ID, April 19-20, $\underline{1974}$.

6. L. H. Kumamoto, Microseismicity Investigation of the Raft River Valley, Idaho, Colorado School of Mines, Golden, CO, 1976, unpubl ished report to $\overline{D O E}-I$ daho Operations Office.

7. S. Schaff, Induced Seismicity Studies at Roosevelt Hot Springs Thermal Area, Utah and Raft River Geothermal Project, Idaho, September 30, 1980, University of Utah Research Institute, 1981, unpublished report to DOE-Idaho Operations Office.

8. S. Schaff, private communication, University of Utah Research Institute, March 1981.

9. W. 0. Ursenbach, W. H. Edwards, J. S. Allan, Baseline Environmental Studies in the Raft River Valley, University of Utah Research Institute, 1976, unpublished report submitted to DOE-Idaho Operations office.

10. D. Crow, and K. Reheis, Raft River Particulate Monitoring Project Monthly Report: November 1980, Erco, Inc., 1981, unpublished report submitted to EG\&G Idaho, Inc.

11. D. Crow, and K. Reheis, Raft River Particulate Monitoring Project Monthly Report: October T980, Erco, Inc., 1981, unpublished report submitted to EG\&G Idaho, Inc.

12. K. Reheis, private communication, Erco, Inc., March, 1981.

13. J. S. Allan, Vegetation Terrestrial Ecology Studies at the Raft River KGRA, 1978-1979, by University of Utah Research Institute, 1980 , unpublished report submitted to EG\&G Idaho Inc. 
14. J. R. Barnes, D. K. Shiozawa, A Description and Assessment of the Raft River Lotic System in the Vicinity of the Raft River Geothermal Area, Brigham Young University, 1980, unpublished report submitted to EG\&G Idaho, Inc.

15. T. L. Thurow and J. F. Sullivan, 1979 Annual Report, INEL Geothermal Environmental Program, EGG-2028, T980.

16. D. W. Hayne, "An Examination of the Strip Census Method for Estimating Animal Populations," J. Wildlife Mgt., 13, 1949, pp. 145-157.

17. J. E. Gross, L. C. Stoddart and F. H. Wagner, "Demographic Analysis of a Northern Utah Jackrabb it Population," Wildlife Monog., No. 40, 1974.

18. J. S. Green and J. T. Flinders, "Habitat and Dietary Relationships of the Pygmy Rabbits," J. Range Mgt., 33, 1980, pp. 136-142.

19. L. Eberhart, "A Preliminary Appraisal of Line Transects," J. Wildlife Mgt., 32, 1968, pp. 82-88.

20. C. M. Woolf, Principles of Biometry, D. Van Nostrand Co., Inc., New York, 1968.

21. D. Muller-Dombois and H. Ellenberg, Aims and Methods of Vegetation Ecology, John Wiley and Sons, New York.

22. R. Daubenmire, "A Canopy Coverate Method of Vegetational Analysis," Northwest Sci., 33, 1959, pp. 43-64.

23. J. T. Curtis and R. P. McIntosh, "The Upland Forest Continuum In the Prairie-Forest Border Region of Wiscons in," Ecology, 32, 1952, pp. 476-496.

24. F. H. Wagner and L. C. Stoddart, "Influence of Coyote Predation of Black-tailed Jackrabb it Populations in Utah," J. Wildlife Mgt., 36 , 1972, pp. 329-342.

25. R. R. Lechleitner, "Movement, Density and Mortality In a Black-tailed Jackrabb it Population," J. Wildlife Mgt., 22, 1958, pp. 371-384.

26. 0. W. Tiemeier, The Black-tailed Jackrabbit in Kansas, Kansas Agricultural Experiment Station, Technical BulTetin 140, 1965, pp. 5-37.

27. D. B. Wilde, A Population Analysis of the Pygmy Rabbit (Sylvilagus idahoensis), PhD thesis, Idaho State University, PocatelTo, 1978.

28. D. E. Bush, W. A. deGraw and W. C. Clampitt, Raptor Res., 12, 1978, pp. $122-125$. 
29. T. L. Thurow, C. M. White, R. P. Howard and J. F. Sullivan, Raptor Ecology of Raft River Valley, Idaho, EGG-2054, 1980.

30. C. D. Jorgensen, C. M. White, C. L. Pritchett, Raft River Environmental Studies, Brigham Young University, pp. 3.T-3.8, unpublished report submitted to DOE-Idaho Operations office

31. F. S. L. Williamson, M. C. Thompson and J. Q. Hines. "Avifaunal Investigations," N. J. Willimousky and J. N. Wolfe (eds.), cited in: Environments of the Cape Thompson Region, Alaksa, USAEC Report PNE -48T, 1966 p. 437-488.

32. C. M. White, F. S. L. Williamson and W. B. Emison, "Avifaunal Investigations," (in press), cited in: The Environments of Amchitka Island, Alaska, M. L. Merrit and R. G. FuTler (eds.), USAEC/TID 267T2, Oak Ridge, Tennessee, 1977.

33. W. C. Lewis, The Socioeconomic Environment of Cassia County, Idaho and Prel iminary Impact Projections of Geothermal Resource Development at Raft River, Lewis and Associates, Logan, Utah, 1979, unpubTished report submitted to EG\&G Idaho, Inc.

34. W. C. Lewis, Detailed Socioeconomic Impact Projections of Geothermal Resource Deve Topment in South Cassia County, Idaho, 1980-1986, Lewis and Associates, Logan, Utah, 1980, unpublished report submitted to EG\&G Idaho, Inc.

35. J. L. Shupe, A. E. 0lson, H. B. Peterson, Incidence of Human Dental Fluoros is in the Raft River Geothermal Area in Southern Idaho, Utah State Research Foundation, 1978, unpublished report submitted to EG\&G Idaho, Inc.

36. J. L. Shupe, private communication, Utah State University, EG\&G Idaho, Inc. 1981.

37. C. F. Hurst, private communication, examining dentist, EG\&G Idaho, Inc., 1981. 